PEDRO HENRIQUE ARCAIN RICCETTO

\title{
STRIKING DOWN CONSTITUTIONAL AMENDMENTS: When Do Courts Enhance Democracy in Latin America?
}

\author{
Ph.D. Dissertation
}

Supervisor: Assistant Professor Conrado Hübner Mendes

\author{
UNIVERSITY OF SÃo PAULO \\ FACULTY OF LAW \\ SÃo PAUlO - SP
}

2020 
PEDRO HENRIQUE ARCAIN RICCETTO

\title{
STRIKING DOWN CONSTITUTIONAL AMENDMENTS: When Do Courts Enhance Democracy in Latin America?
}

Thesis submitted in partial fulfilment of the requirements for the degree of Ph.D. in Public Law (Constitutional Law) at University of São Paulo, Faculty of Law, under the supervision of Assistant Professor of Law Conrado Hübner Mendes.

\author{
UNIVERSITY OF SÃO PAULO
}

FACULTY OF LAW

SÃo PAUlo - SP

2020 
Catalogaçăo da Publicaçăo Serviço de Biblioteca e Documentação

Faculdade de Direito da Universidade de São Paulo

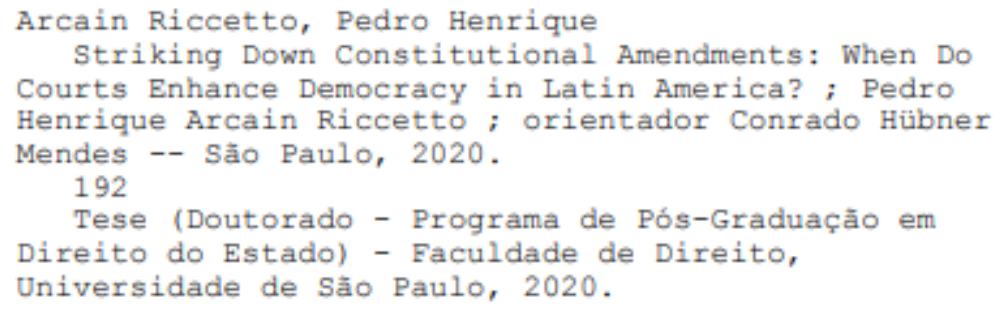

1. Public Law. 2. Judicial Politics. 3. Courts. 4. Constitutional Amendments. 5. Latin America. I. Mendes, Conrado Hübner, orient. II. Título. 


\section{ACKNOWLEDGEMENTS}

The doctoral experience was life-changing for me, and I owe many thanks for what I have learned. During the past years, I crossed paths with brilliant, inspiring, and supportive people. Each of them made me thankful for the opportunities I had and thrilled about what comes next. My frankest gratitude to Professors Conrado Mendes, who gently guided me throughout this expedition as my supervisor, and Sergio Resende de Barros, who first trusted me as his doctoral supervisee. This journey would not have been viable without their work. I also wish to thank the readers of this dissertation, Professors Rogério Arantes, Virgílio Afonso da Silva, Luciana de Oliveira Ramos, and Diego Werneck Arguelhes, for their time and feedback.

The academic environment may be hostile to some, but what I found at the University of São Paulo was a group of colleagues fully dedicated to cooperation. I wish to thank to the good friends I have made here, for their partnership inside and outside the classroom: Túlio Jales, Nicola Tommasini, Beatriz Kira, Lívia Guimarães, Enrico Misasi, Cecília Barreto, Pedro Banhos, Vivian Rocha, Bonifácio Andrada, Lilian Cintra, Karina Denari, Gabriel Calil, Beatriz Nimer, Guilherme Jardim Duarte, Jeferson Mariano Silva, Matheus Souza, Victor Marcel, among others. Also, I am grateful for all the support provided by the research cluster "Constitution, Politics, and Institutions" and its members.

During these years, I was incredibly lucky to have the possibility of pursuing research abroad. I had the pleasure of being a visiting researcher at Yale University's Department of Political Science, under the guidance of Professor Frances Rosenbluth. Her friendship, dedication and inputs were essential for my development as a researcher, and our weekly lunch discussions at the Dining Hall were the highlights of my stay. Yale has grown the sense of community in me, and I would like to give special thanks to Rafael Bezerra Nunes, Raquel Mattos Pimenta, Guilherme Palu, Renan Kalil, Cathy Greene, Antonio Davola, Fernando Bracaccini, Paula Perez, Franziska Bantliin, Anat Lior, and Quirin Weinzierl.

I undertook a pre-doctoral fellowship at the University of Oxford, position that was sponsored by Professor Ezequiel Gonzalez-Ocantos, to whom I will always be indebted for his generosity and advice. I also want to show my gratitude for the Latin American Centre and the dedication of Professors Tim Power and Andreza Aruska. I also need to thank Luis Fernando Matricardi, Bernardo Medeiros, Cristina Maglia, 
Leonardo Gil, Pedro Felipe Santos, Filip Bubenheimer, Darlan Cândido, and the Brazilian Society members. Special thanks to Baroness Shas Sheehan for giving me the chance to learn from the UK Parliament daily activities. Also, I could not skip the mention to 10 Rectory Road (and Rosanna, Tom, Ellie, and Angharad), a house that will always be in my heart.

I thank Professor Scott Mainwaring for granting me the Democratic Governance Fellowship at Harvard Kennedy School. I definitely benefited from his supervision and insightful comments. The period I spent there was highly productive and I learned a lot from the community of scholars engaged in politics and policy-making in Latin America. I am grateful for the frequent discussions I had with Kaori Urayama, Candelaria Garay, Daniel Hidalgo, Aisha Moodie-Mills, Heidi Heitkamp, and Roger Stiefelmann Leal.

I am indebted to many other scholars for their help in many stages of my doctoral journey. For commenting on pieces of this dissertation or papers I wrote for events, I would like to thank Daniel Cappechi, Renê Chiquetti, Vera Chueiri, Yaniv Roznai, Linda Greenhouse, and Lee Epstein. I am also grateful for the insights I received from David Landau, Ran Hirschl. I am equally thankful to the researchers I met in the short research periods I spent at the Max Planck Institute in Heidelberg and Sciences Po Paris.

I empashize my thanks for the financial support received from CAPES, which funded in more than opportunity my research through scholarships and travel grants. It is also thanks to CAPES that I was able to conduct my doctoral research in other countries.

Parts of the section 2.1 of this dissertation (especially 2.1.1.1) were adapted from a paper I co-authored with Nicola Tommasini and Yaniv Roznai, entitled "When Overrides and Backlashes Do Not Scare: The Power to Review Constitutional Amendments and the Case of Brazil" (not published yet). I thank the co-authors for giving me permission to integrate the argument of the paper to the broader argument developed here.

I would like to thank my family - my mother, my father, my sister and my nephew - for all their support from when I decided to follow the academic path. 
Pursuing a PhD was only possible because of their love, hard work and trust in me, and receiving this degree will be fully dedicated to them.

Finally, this would not have been possible without the tireless help of my husband, Paul-Louis Lecomte. He was my biggest supporter, advisor and discussant. From when we met in those tiny streets full of castle-like buildings in Oxford, I was sure I had found a partnership for life. At that time, I was looking for answers for my research, but I ended up finding something much more precious. To him, my deepest thanks. 
RICCETTO, Pedro Henrique Arcain. Striking Down Constitutional Amendments: When Do Courts Enhance Democracy in Latin America? January 2020, 190 pages, Ph.D. Dissertation, Faculty of Law, University of São Paulo, São Paulo.

\begin{abstract}
The role of the Courts in the review of constitutional amendments is often pictured as a detractor of the democratic quality of a political system, as many scholars argue it endangers the will of a qualified elected majority. However, there may be cases where the judicial intervention enhances democracy by improving the political decisionmaking standards. The dissertation aims to answer under which circumstances the power granted to justices to review constitutional amendments produces democratic outcomes. To address the question, I considered institutional and political settings of several Latin American countries (Argentina, Brazil, Colombia, and Peru) and performed a comparative analysis to test whether the presence or absence of some variables allows a democratic judicial review of constitutional amendments. The political and institutional attributes discussed are (I) Judicial Independence, (II) Political Competition, and (III) Legitimacy of the Courts, identified from previous literature in judicial politics. I tested if the presence of these variables fulfils three criteria established as a measure for democracy: (i) the existence of deliberative processes inside and outside the courts, (i) the possibility of overrides and backlashes, and (iii) the nonpartisanship of the judicial rulings, in the review of constitutional amendments. I then chose two countries for the testing of each attribute (I, II, III), one where this attribute is present and another where it is absent. For testing this model, I adopted the rational choice theory applied to judicial behaviour. The results show that the presence of some combinations of institutional attributes enhance the democratic quality of the judicial review of constitutional amendments. The dissertation intends to provide scholars with a better understanding of the constitutional amendment dynamics. It also aims to develop a tangible guide to assist constitutional practitioners on deciding the role of the courts in the judicial review of constitutional amendments and determining what are the best institutional scenarios for granting justices with this power.
\end{abstract}

Keywords: Judicial Politics; Courts; Constitutional Amendments; Latin America. 
RICCETTO, Pedro Henrique Arcain. Control de Enmiendas Constitucionales: ¿Cuándo Consiguen las Cortes Mejorar los Estándares Democráticos en América Latina? Enero de 2020, 190 páginas, Tesis Doctoral, Facultad de Derecho, Universidad de São Paulo.

\section{RESUMEN}

El papel las Cortes en el control de enmiendas constitucionales suele ser considerado como un detractor de la calidad democrática de un sistema político, ya que muchos argumentan que un grupo de jueces non elegidos puede rebatir la voluntad de una mayoría elegida y cualificada. Sin embargo, es posible que existan casos en los que la intervención judicial resulta más democrática gracias a la mejora de la calidad de las decisiones políticas. Esta tesis tiene por objetivo entender bajo qué circunstancias el poder otorgado a los Ministros para controlar enmiendas produce resultados democráticos. Para responder a esta pregunta, considero el marco político e institucional de varios países Latinoamericanos (Argentina, Brasil, Colombia y Perú) para realizar un análisis comparativo y definir si la presencia o ausencia de una serie de Atributos Institucionales contribuye a un control judicial de enmiendas constitucionales más democrático. Estos Atributos Institucionales son: (I) Independencia Judicial, (II) Competencia Política y (III) Legitimidad de la Corte, basados en literatura previa sobre política judicial. En mi estudio, evaluó si la presencia de estos atributos satisface tres criterios que establezco como medidas de democracia: (i) la existencia de procesos de deliberación de la Corte, (ii) la posibilidad de oposición a la decisión judicial o a la Corte, (iii) la imparcialidad de las decisiones judiciales, en el control de enmiendas constitucionales. El análisis es comparativo, lo que significa que para evaluar el aporte de cada Atributo Institucional (I, II, III) escojo un país donde el atributo está presente y otro en el que está ausente. Cabe mencionar que, a lo largo del desarrollo del análisis de este modelo, utilizo la teoría de elección racional aplicada al comportamiento judicial. Los resultados muestran que algunas combinaciones de Atributos Institucionales mejoran la calidad democrática del control judicial de enmiendas constitucionales. Esta tesis pretende ofrecer un mayor entendimiento de las prácticas y dinámicas del control de enmiendas constitucionales para académicos e investigadores. También tiene por objetivo desarrollar una guía practica para ayudar a determinar el papel de las cortes en el control de enmiendas constitucionales y determinar cuáles son los escenarios en los que otorgar este poder a los Ministros es más adecuado.

Palabras Clave: Política Judicial, Cortes, Enmiendas Constitucionales, América Latina 
RICCETTO, Pedro Henrique Arcain. Controle Judicial de Emendas Constitucionais: Democracia e Constitucionalismo na América Latina. Janeiro de 2020, 190 páginas, Tese de Doutorado, Faculdade de Direito, Universidade de São Paulo.

\section{RESUMO}

O papel das Cortes no controle de emendas constitucionais é usualmente considerado deletério à qualidade democrática de um sistema político, uma vez que permite a um grupo de juízes não eleitos confrontar a vontade de uma maioria eleita e qualificada. No entanto, é possível que a intervenção judicial resulte em mais democracia e, portanto, melhore a qualidade da decisão política. Esta tese tem como objetivo entender sob quais circunstâncias o poder de controlar emendas concedido às Cortes Constitucionais produz resultados democráticos. Para responder à pergunta, considero particularidades políticas e institucionais de diversos países latino-americanos (Argentina, Brasil, Colômbia e Peru) para realizar análise comparativa e definir se a presença ou ausência de uma série de Atributos Institucionais contribui para um controle de emendas constitucionais mais democrático. Baseado em literatura prévia sobre política judicial, defino que esses Atributos Institucionais são: (I) Independência Judicial; (II) Competição Política; e (III) Legitimidade das Cortes. No estudo, avalio se a presença desses atributos satisfaz três critérios que estabeleço como medidas de democracia: (i) a existência de processos de deliberação na Corte; (ii) a possibilidade de oposição à decisão judicial ou à Corte enquanto instituição; e (iii) a imparcialidade das decisões judiciais, todos verificados dentro do controle de emendas constitucionais. A análise é comparativa, o que significa que para avaliar a contribuição de cada Atributo Institucional (I, II, III) eu escolho um país onde o atributo está presente e outro em que está ausente. Cabe mencionar que, ao longo do desenvolvimento da análise deste modelo, utilizo a teoria da escolha racional aplicada ao comportamento judicial. Os resultados mostram que algumas combinações de Atributos Institucionais melhoram a qualidade democrática do controle judicial de emendas constitucionais. Esta tese pretende oferecer um melhor entendimento das práticas e dinâmicas do controle de emendas constitucionais para acadêmicos e investigadores. Também tem por objetivo desenvolver um guia prático para ajudar a determinar o papel das Cortes no controle de emendas constitucionais e estabelecer quais são os cenários em que conceder esse poder aos Ministros é mais adequado.

Palavras-Chave: Política Judicial, Cortes Constitucionais, Emendas Constitucionais, América Latina. 


\section{TABLE OF CONTENTS}

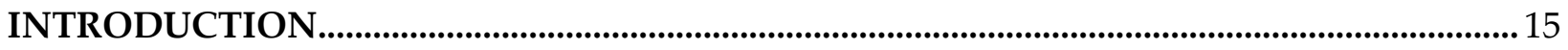

CHAPTER 1 - BUILDING A MODEL FOR ASSESSING THE DEMOCRATIC QUALITY OF THE JUDICIAL REVIEW OF CONSTITUTIONAL AMENDMENTS .....................................22

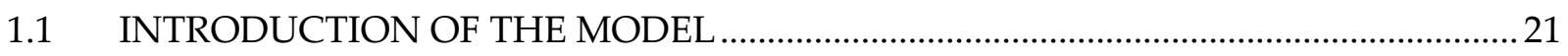

1.2 A RATIONAL CHOICE APPROACH TO THE RESEARCH PROBLEM.............................29

CHAPTER 2 - INSTITUTIONAL ATTRIBUTES AND JUDICIAL BEHAVIOUR ....................33

TESTING THE MODEL IN LATIN AMERICAN COUNTRIES ...................................................33

2.1 PROVING THE IMPACT OF JUDICIAL INDEPENDENCE ON THE DEMOCRATIC QUALITY OF THE JUDICIAL REVIEW OF CONSTITUTIONAL AMENDMENTS .................35

2.1.1 The Case of Brazil: Excessively High Levels Of Judicial Independence In The Supreme Court .....................................................................................................................................................38

2.1.1.1 Impact on the Possibility of Overrides and Backlashes ........................................39

2.1.1.2 Impact on Deliberation ....................................................................................................... 48

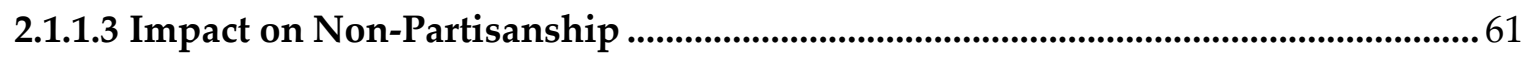

2.1.2 The Case of Argentina: The Lack of Independence of The Court ................................ 63

2.1.2.1. Impact on the Possibility of Overrides and Backlashes ........................................... 65

2.1.2.2 Impact on Deliberation ............................................................................................................ 68

2.1.2.3 Impact on Non-Partisanship ......................................................................................... 71

2.1.3 Partial Conclusions Of The Effects Of Judicial Independence .......................................73

2.2 PROVING THE IMPACT OF POLITICAL COMPETITION ON THE DEMOCRATIC QUALITY OF THE JUDICIAL REVIEW OF CONSTITUTIONAL AMENDMENTS ................76

2.2.1 The Case of Brazil: Low Political Competition Caused By Strong Presidential

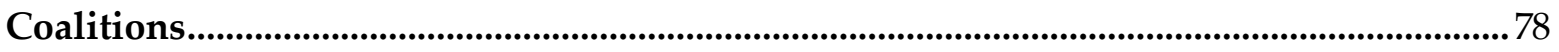

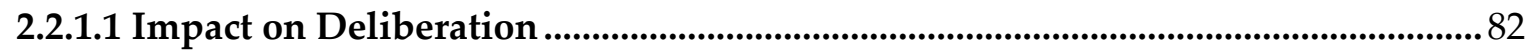

2.2.1.2 Impact on the Possibility of Overrides and Backlashes ............................................ 85

2.2.1.3 Impact on Non-Partisanship ............................................................................................ 86 
Figure 21. Peruvian Congress composition (1992-2006) ….................................................. 95

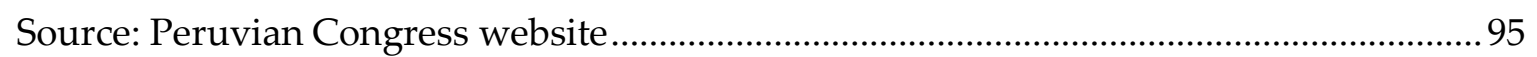

Figure 22. Peruvian Congress Composition (1992-today) Source: Peruvian Congress

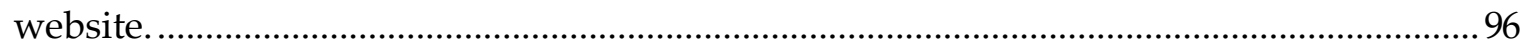

2.2.2.1 Impact on Deliberation ......................................................................................................97

2.2.2.2 Impact on the Possibility of Overrides and Backlashes .......................................99

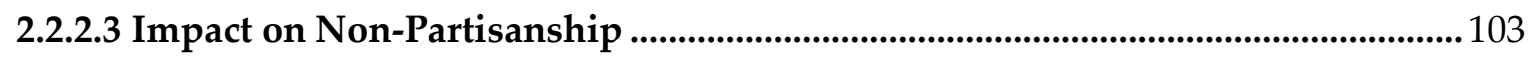

2.2.3 Partial Conclusions On The Effects of Political Competition .....................................106

2.3 PROVING THE IMPACT OF LEGITIMACY OF A COURT ON THE DEMOCRATIC QUALITY OF THE JUDICIAL REVIEW OF CONSTITUTIONAL AMENDMENTS ...............108

2.3.1 The Case of Colombia: A Highly Legitimate Supreme Court...................................... 112

2.3.1.1 Impact on Deliberation ....................................................................................................... 113

2.3.1.2 Impact on the Possibility of Overrides and Backlashes .......................................... 117

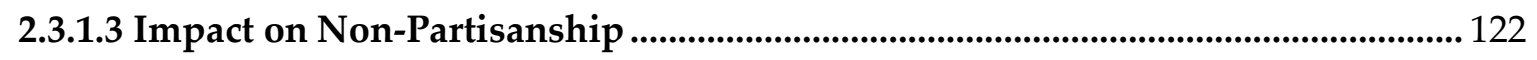

2.3.2 The Case of Brazil: Legitimacy Crisis in the Supreme Court .................................... 126

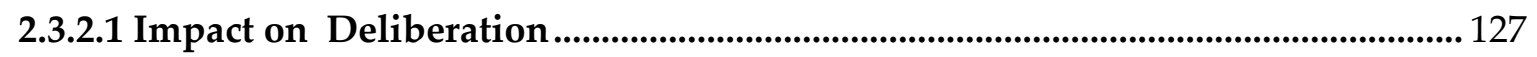

2.3.1.2 Impact on the Possibility of Overrides and Backlashes ...................................... 131

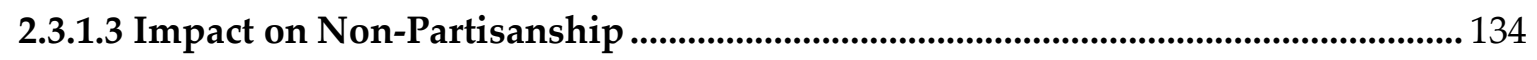

2.3.3 Partial Conclusions On The Effects of Legitimacy Of The Courts ............................... 138

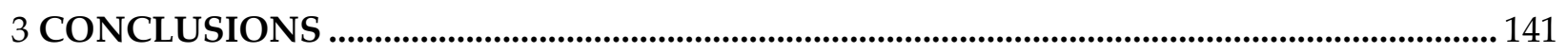

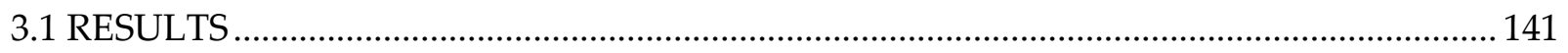

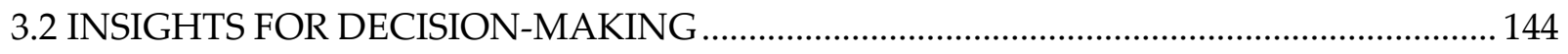

Annex 1 - Judicial Review Of Constitutional Amendments In Brazil (1988-2018) ...................... 150

Annex 2 - Brazilian Supreme Court Decisions Reviewing Constitutional Amendments............ 161

Annex 3 - Peruvian Constitutional Court Decisions Reviewing Constitutional Amendments .. 180

Annex 4 - Brazilian Justices Appointed By Each President .......................................................... 182

Annex 5 - Colombian Constitutional Court Decisions Reviewing Constitutional Amendments 


\section{LIST OF FIGURES}

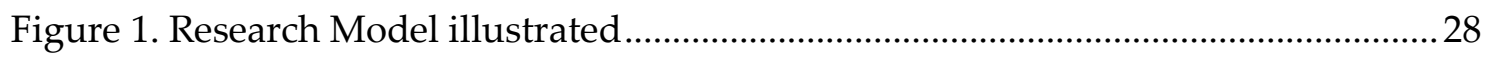

Figure 2. Amicus Curiae Petitions Across Time in JRCA cases. Brazilian Supreme

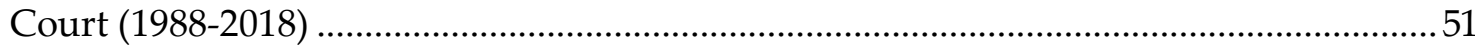

Figure 3. Participation of the Senate in JRCA cases. Brazilian Supreme Court (19882018) .52

Figure 4. Percentage of preliminary rulings in JRCA cases. Brazilian Supreme Court (1988-2018) .53

Figure 5. Percentage of individual rulings confirmed by the plenary in JRCA. Brazilian

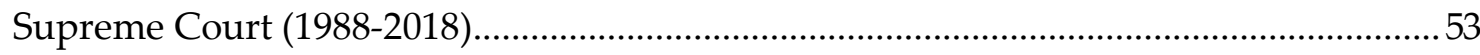

Figure 6. Length of "Pedidos de Vista" in JRCA cases. Brazilian Supreme Court (19882018) .54

Figure 7. Participation of amici curiae by category in JRCA cases. Brazilian Supreme Court (1988-2018) .57

Figure 8. Public Corporations as amici curiae in JRCA cases. Brazilian Supreme Court .58

Figure 9. Participation of the House of Representatives in JRCA cases. Brazilian Supreme Court (1988-2018). .59

Figure 10. Presidential Coalition Strength in Brazil under Lula I and II (2003-2010).....79

Figure 11. Presidential Coalition Strength in Brazil under Dilma I and II (2011-2016) .. 80

Figure 12. Composition of the Brazilian House of Representatives (2003-2006).............81

Figure 13. Composition of the Brazilian House of Representatives (2007-2010).............81

Figure 14. Percentage of Amendments ruled unconstitutional (partially or fully) by the

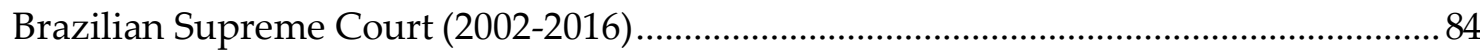

Figure 15. Percentage of the amendments ruled unconstitutional (partially or fully) by the Brazilian Supreme Court (1994-2016) .85

Figure 16. Percentage of vote cohesion by Brazilian justices appointed by the same President in all abstract review cases (1988-2016) . .88 
Figure 17. Percentage of vote cohesion by Brazilian justices appointed by the same President in JRCA cases. Brazilian Supreme Court (1988-2018) ....................................... 89

Figure 18. Brazilian justices' ideal points $(1990-2002)$......................................................91

Figure 19. Brazilian justices' ideal points (2003-2010) ......................................................91

Figure 20. Percentage of justice's blocks cohesion per government in JRCA. Brazilian

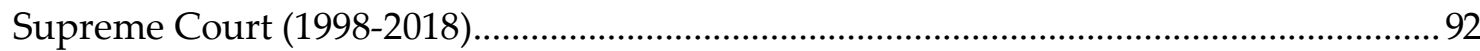

Figure 21. Peruvian Congress Composition (1992-2006) .................................................. 92

Figure 22. Peruvian Congress Composition (1992-today) …..........................................92

Figure 23. Percentage of amendments ruled unconstitutional by the Peruvian Constitutional Court (2001-2018)

Figure 24. Outcome of individual opinions in all JRCA cases in Peru. Peruvian

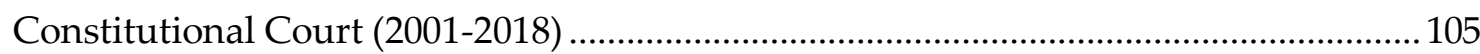

Figure 25. Average Trust in the Colombian Constitutional Court (2006-2016) .............109

Figure 26. Average Trust in the Brazilian Supreme Court $(2012,2017,2018)$................ 110

Figure 27. Justices Gilmar Mendes, Carmen Lúcia and Edson Fachin approval rates.

Brazilian Supreme Court (2017) .................................................................................... 112

Figure 28. Average number of interventions per case in JRCA in Colombia Colombian Constitutional Court (1993-2017)

Figure 29. Number of interventions in cases of JRCA in Colombia - Colombian Constitutional Court (1993-2017) 116

Figure 30. Number of Constitutional Law Experts on the Colombian Constitutional Court (1993-2012) 123

Figure 31. Percentage of the population that trusts in the Colombian Constitutional Court $(2010,2016)$

Figure 32. Average Number of Interventions per JRCA case. Brazilian Constitutional Court (1993-2016) 128

Figure 33. Categories of Intervention in the JRCA cases. Brazilian Supreme Court (1993-2016). 130

Figure 34. Number of Constitutional Amendment Proposals to Modify the Brazilian Supreme Court (2002-2019).

Figure 35. Forecasted Success of Judicial Review of Constitutional Amendments Decision Tree 


\section{LIST OF ABBREVIATIONS}

AC - "Ação Cautelar"

AI - "Acción de Inconstitucionalidad"

ADI - "Ação Direta de Inconstitucionalidade"

ADPF - "Ação de Descumprimento de Preceito Fundamental"

CA - Constitutional Amendment

CCC - "Corte Constitutional de Colombia"

C-No - Country-No

CSJ - "Corte Suprema de Justicia de La de la Nácion Argentina"

C-Yes - Country-Yes

ENP - Effective Number of Parties

FSR - Forecasted Success Rate

JR - Judicial Review

JRCA - Judicial Review of Constitutional Amendments

PCA - Proposal of Constitutional Amendment

STF - "Supremo Tribunal Federal"

TC - “Tribunal Constitucional" (Peruvian)

TRF - "Tribunal Regional Federal" 


\section{INTRODUCTION}

When should justices have the power to review constitutional amendments? How can the judicial power to review such amendments allow democratic decisions? The democratic implications of granting judges the power to review statues have long been debated. Justices are unelected officials that may nonetheless strike down legislation enacted by the parliament, and the lack of accountability when exercising this power could lead them to become uncontrollable and subvert democracy ${ }^{1}$. For some scholars, the aptitude to be invested in their roles without going through periodic elections would have a negative impact on their authority to strike down legislation (Tushnet, 2000; Kramer, 2005; Waldron 1999; 2006). Being able to hold their position would blind the justices from the longings of society, isolating policy-making from the difficulties inherent to democratic politics and thus resulting in what is sometimes called "juristocracy" (Hirschl, 2007).

Whether these theories are accurate or not, there is a need to justify judicial review. The tension created by unelected judges overruling the will of an elected majority - the counter-majoritarian difficulty (Bickel, 1986) - has always raised issues that have important implications for democracy. Putting in question the role of judges could drastically alter the dynamics of democratic decision-making by impacting the balance between Powers. The issue, however, matters beyond procedural aspects and has an impact on the concept of democracy itself, once judges would be responsible for protecting minorities from pure majoritarianism. ${ }^{2}$

This debate has always been relevant, but one of the most meaningful discussions on the effects of judicial review to democracy was held in the Philadelphia

\footnotetext{
${ }^{1}$ See The Anti-Federalist Papers N. 78-79 (C. Kenyon ed. 1966).

${ }^{2}$ See The Federalist n. 78 (Dutton ed. 1948).
} 
Convention (1787), during the conception of the American Constitution. For the Federalists -judicial review partisans- the legislative authority could only be preserved if courts were adopted as moderators of the will of the majority. On the other side, the Anti-Federalists, opposed to the power of reviewing legislation, were insisting on the potential tyranny of judges. This debate has also received attention lately given the court's increasing importance in constitutional systems. In 2008, courts granted with this power were present in 139 countries, representing the greatest part of the democratic systems in the world ${ }^{3}$. This is the result of the increasing relevance of courts worldwide after World War II, when courts started becoming the main protectors of fundamental rights (Ginsburg, 2008).

The question of why judges should have the power to review the laws has been the center of intense academic controversy. However, little has been discussed about how this power is applied to constitutional amendments processes. The judicial review of constitutional amendments is, in many countries, taken for granted, as a pure extension of the power to strike down statutes. For instance, the Brazilian Supreme Court decided to grant itself the powers to strike down constitutional amendments in 1993, amplifying the scope of their ordinary powers to review the laws ${ }^{4}$. Just as in Brazil, many other courts have been progressively embracing this power to review constitutional amendments. India, Colombia, Romania, Angola, Switzerland, Portugal, Turkey and Taiwan are countries in which supreme courts have the power to review and invalidate amendments, proving the growing popularity of this practice. But, does this power extension represent a danger for democracy?

\footnotetext{
${ }_{3}^{3}$ According to Tom Ginsburg (2008), 79 written constitutions have provisions creating a constitutional court or a council to review the laws, while other 60 have provisions for judicial review by a supreme court or ordinary courts.

${ }^{4}$ See "Ação Direta de Inconstitucionalidade" - ADI N. 829/1993. Further analysis of this case of Brazil will be made on Chapter 2.1.
} 
The difficulties of extending judicial review to constitutional amendments have been pointed out in some occasions ${ }^{5}$, but they are critical given that amendments are a higher representation of the will of the people (Albert, 2009). Constitutional amendments are the result of the consensus of super-majorities to make a change, thus discussing the existence of this power becomes increasingly important. If the countermajoritarian difficulty is a relevant question for democratic theory, debating the judicial review of constitutional amendments is central, as the impact of striking down an amendment is presumably more undemocratic than striking down an ordinary law.

More importantly, nothing has been discussed about the circumstances under which courts are able to make democratic decisions when reviewing constitutional amendments. Assuming this power is granted to justices, it is critical to find out how judicial review of constitutional amendments can result in democratic decisions. What institutional variables matter for the achievement of democratic decisions in judicial review of constitutional amendments? Under which scenarios can giving this power to judges be an effectively democratic measure? These questions derive from the broader question of whether judicial review is compatible with democracy. However, this more specific issue deserves special attention as its answer will allow an enhancement of judicial decision-making for fostering democracy. The dissertation aims to find out the optimal conditions to grant this power to justices will help guaranteeing that the most democratic procedure is applied in every different country.

In countries where judges are empowered to review amendments, I will perform a cross-country comparative analysis to answer the research question: Under which institutional circumstances the judicial review of constitutional amendments enhances democracy? I will go through the countries' institutional characteristics to evaluate

\footnotetext{
${ }^{5}$ For scholarship tackling the issue, see, e.g., Mendes, Conrado Hübner (2005), "Judicial Review of Constitutional Amendments in the Brazilian Supreme Court". Florida Journal of International Law, v. 17; and Roznai, Yaniv (2017) Unconstitutional Constitutional Amendments. Oxford University Press.
} 
which factors ensure the democratic functioning of this procedure. The comparative approach will enable the measurement of the democratic impact of granting this power to judges in a certain institutional layout. After performing the analysis, we should be able to assert in which cases the power to strike down constitutional amendments enhances democracy and in which it does not.

The research design focuses on Latin American countries in which the power of judges to review amendments is present. I will define a set of variables -guided by previous legal and political science studies- to justify the presence of a democratic system of judicial review of amendments. In every country, I will assess under which institutional circumstances these variables exist. This will allow us to prove that a democratic outcome is possible when in the presence of certain institutional attributes.

Based on previous literature on judicial politics, I define that the variables indicating the presence of a democratic judicial review of constitutional amendments are: Deliberation (i), or the existence of deliberative processes inside and outside the court; The Possibility of Overrides and Backlashes (ii) of judicial decisions that review constitutional amendments; and the perceived Non-Partisanship (iii) of this judicial ruling. I therefore consider that the judicial review of constitutional amendments is more democratic when these variables, that I call Democratic Criteria, are met.

These Democratic Criteria will be tested in countries in which of the following Institutional Attributes are present or absent: Judicial Independence (I), Political Competition (II), and Legitimacy of the Courts (III). In my analysis, I will confirm if the Democratic Criteria (i, ii and iii) are met in every country-case, to prove that the presence of these Institutional Attributes allows a democratic judicial review of amendments. Finally, based on this analysis, I will assess under which combination of Institutional Attributes (I, II and III) the power to review amendments should be allocated to courts. 
Although there are correlations amongst (I), (II), (III), every attribute will be tested separately to isolate the focus attribute and ensure a structured flow. For every Institutional Attribute respectively, I chose the case of a country in which the attribute is present (Country-Yes) and another country in which the attribute is not present (Country-No). For Judicial Independence (I), Country-Yes will be Brazil, where the Supreme Court has gained an undisputed power and is nowadays responsible for mediating virtually every political conflict in the country, acting with complete independence. Country-No will be Argentina, where the Supreme Court, despite varying across time, is known for its low level of Judicial Independence. For the Political Competition attribute (II), Country-Yes will be Peru, given the presence of highly divided political authority in the elected bodies, party volatility and weak Presidents. Country-No will be Brazil from 2003 to 2010, where the Executive held a consistent coalition in Parliament, notwithstanding the high number of parties in Congress. Lastly, regarding the Legitimacy of the Courts (III), Country-Yes will be Colombia, which is known by the popular support given to its Supreme Courts. Country-No will be Brazil, in which the Courts' popularity has fallen significantly due to its poor mediation of political conflicts.

This cross-country comparison will allow me to prove my main hypothesis (H1), which is that the presence (or absence in some cases) of the Institutional Attributes (I, II, III) in a country allows democratic decisions in the judicial review of constitutional amendments, by meeting our Democratic Criteria (i, ii, iii).

The fact that the research is made only in Latin American countries enables us a better isolation of the influence of the attributes studied, given that all countries share macro-institutional similarities. All of them share the same type of government, civil law system, and they all are constitutional democracies with a very similar level of 
consolidation of the rule-of-law6 ${ }^{6}$. However, while the study focuses on Latin American countries, it has much broader implications as the question of judicial review of constitutional amendments is becoming one of the most burning questions in global constitutionalism (Roznai, 2017; Yap, 2015; Halmai, 2012).

I will start the first chapter of this dissertation reviewing the scholarship that have tackled the issue of judicial review and how it relates to democracy. Theories which support or are against granting this power to judges will be discussed. From these theories, I will then set the normative guidelines of our study, justifying the set of variables which are indicators of the presence of a democratic system (Democratic Criteria). To finish building the model, I justify the chosen set of Institutional Attributes that I consider as triggering the correct functioning of the judicial power to review constitutional amendments. This will pave the way for us to justify the set of hypotheses tested in the second chapter of this study. Each hypothesis sets the guidelines to evaluate the effects of each Institutional Attribute on the fulfillment of the Democratic Criteria.

In the second chapter I will dive into the comparative analysis, which will be split into three parts, mirroring our three Institutional Attributes. The first part will address the issue of Judicial Independence, the second tackles Political Competition and the third Legitimacy of the Courts. A cross-country qualitative analysis will be performed, comparing a set of two countries in each part. We will then, in the third chapter, extract the overall results and draw conclusions and recommendations to handle the power to review constitutional amendments.

\footnotetext{
${ }^{6}$ The country-cases I will analyse are all constitutional democracies with presidential systems and a "civil law" legal system. In addition to that, all of them are considered "Free" (score 1,1) by the Freedom House Index, have similar scores on the Rule of Law Index ( $\sim 7$ points), and on the Democratic Development Index ( $\sim 9$ points).
} 


\subsection{RESULTS}

We have analysed how the Institutional Attributes (Judicial Independence (I), Political Competition (II), and Legitimacy of the Courts (III)) affect the democratic quality of the judicial review of constitutional amendments. This democratic quality was defined by a set of conditions that I called Democratic Criteria (Deliberation (i), Possibility of Overrides and Backlashes (ii), and Non-Partisanship (iii)). I compared the democratic quality of the judicial review of constitutional amendments in Latin American countries where the Institutional Attributes were present (Country-Yes) and absent (Country-No), respectively. This cross-country comparison allowed me to observe in the presence of which Institutional Attributes the Democratic Criteria were met.

Results for Brazil and Argentina show that Judicial Independence (the degree of freedom of a court from interference of other political actors) does have an important effect on the Democratic criteria. Excessive levels of Judicial Independence represent an obstacle for the democratic review of amendments. In this circumstance, Courts do not have to consider the preferences of other actors when making decisions, which creates a scenario where overrides and backlashes are virtually impossible. Individuality coming from this independence also deteriorates the deliberative standards of a court. Also, the Court does not fear sanctions, which allows them to act in a partial fashion. On the other hand, a level of Judicial Independence that is too low is also detrimental to the democratic quality of the judicial review of constitutional amendments. Courts tend to act strategically in order to protect themselves from overrides, to the point that this power to review amendments becomes useless, given that the Court mirrors the will of the elected bodies, acting partially. The same mechanics apply to deliberation, given 
that the Court's role becomes less relevant in the political decision-making, and there are no incentives for other actors to engage in judicial debates. Hence, an intermediary level of Judicial Independence is needed to allow the correct functioning of a system of checks and balances for the judicial review of constitutional amendments to reach a democratic character. Democracy is endangered if the power to validate amendments is allocated to an over-empowered body (Court or elected bodies), thus a balanced distribution of power is essential for the review of constitutional amendments.

The cases of Peru and Brazil were used for assessing the effects of Political Competition on our Democratic Criteria. We saw that the division of political authority between actors with different preferences inside the elected bodies impacted the democratic quality of the judicial review of amendments. For deliberation, we could see that the higher the levels of Political Competition, the more intense the role of the Parliament becomes in the discussions. This erodes the democratic quality of the judicial review of constitutional amendments by taking deliberation away from the Court. On the other hand, under lower Political Competition, less discussions and consensus are needed in Congress for enacting an amendment, given that debates gather less political actors and this makes it less politically costly for the Court to oppose the elected bodies. This mechanics will bring deliberation inside Courts, calling civil society and the less influent political groups to join the Court in the debate. For Overrides and Backlashes I found that the possibility of overriding the courts exists under cases of low Political Competition, and that it increases as the Political Competition levels decrease. This happens because of the concentration of political authority, which facilitates the achievement of a majority to override the Court. However, under high Political Competition, the Possibility of Overrides and Backlashes vanishes, as confrontation between the elected bodies and the court becomes less likely. 
Legitimacy -or the acceptability and respect to the Court's actions and authority from society- was also an important attribute affecting most of our Democratic Criteria in Colombia and Brazil. Although the effect of the Possibility of Overrides and Backlashes was difficult to find, it did have an impact on Deliberation and NonPartisanship. High Legitimacy enhances the deliberative standards of a Court by creating a bond between the population and the Court. Not only do more actors participate in the judicial review of amendments, but also the quality of the participants is improved. Civil Society, Research Institutes, Universities and other knowledgeable, relevant actors engage to enrich the discussion when Legitimacy is high. The opposite happens in the case of low Legitimacy, where less actors join the debates, and when they do, their motivations to participate are mostly strategic. The Possibility of Overrides and Backlashes was not directly affected by Legitimacy. This attribute only had an impact on the likelihood of running against the Court, but not on its possibility. Regarding the Non-Partisanship, Court with high Legitimacy are more impartial due to the higher levels of institutionalisation it shows. In this case, the existence of a cohesive jurisprudence and a collegiate behaviour refrained justices from acting in partisan ways. Also, it is less likely that a Court that holds strong popular support will make agreements with the elected bodies in order to guarantee compliance with its decisions. Opposingly, a Court with low levels of Legitimacy will not be sufficiently able to constrain its justices from disregarding the collegiate or disobeying the jurisprudence, which fosters partial behaviour. A non-legitimate Court will also be more prone to make deals with the elected bodies or to adopt questionable procedures to fight against popular criticism and secure compliance. 


\subsection{INSIGHTS FOR DECISION-MAKING}

As we have seen in our results, the Democratic Criteria (Deliberation (i), Possibility of Overrides and Backlashes (ii) and Non-Partisanship (iii)) are met in different ways in the presence or absence of our Institutional Attributes (Judicial Independence (I), Political Competition (II) and Legitimacy of the Court (III)). The presence of some Attributes guarantees a more complete fulfilment of the democratic judicial review of constitutional amendments, while other Attributes have a less significant effect on this democratic quality. However, we must understand that, in practice, these Attributes need to be considered in combination. Some of our three Institutional Attributes can be present in a country, while others are absent, making the number of possible combinations rise. In order to determine which combinations of Institutional Attributes are more suitable for the judicial review of amendments, I needed to build a decision tree including all possible combinations. For assessing which

combination means a more -or less- democratic judicial review of amendments, I gave every Attribute a value based on its fulfilment of the Democratic Criteria. For instance, we have seen that the presence of Political Competition (II) fosters Non-Partisanship (iii) but is a detractor of Deliberation (i) and Possibility of Overrides and Backlashes (ii). Hence, the presence of Political Competition is allocated a score of only one (1) point out of three. The allocation of scores per Institutional Attributes can be observed in the table below (Table 1). 


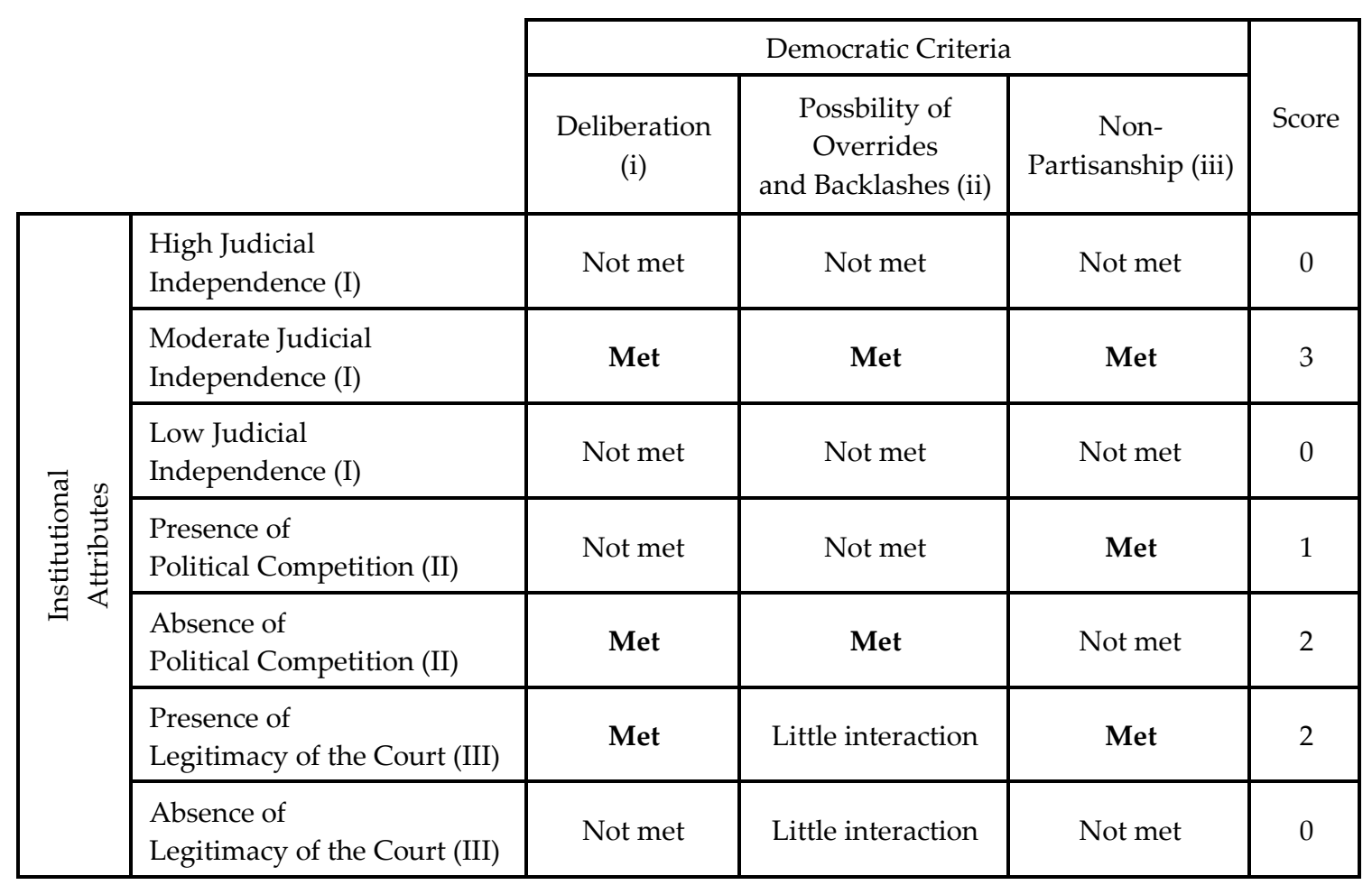

Table 1. Allocation of Scores to the Presence or Absence of Institutional Attributes for the fulfillment of Democratic Criteria.

The results on Judicial Independence showed that a moderate level is needed for the three Democratic Criteria to be met and is actually the Institutional Attribute that brings more democratic value to the judicial review of constitutional amendments (3 points). A country with excessively low or high levels of Judicial Independence could not fulfil any of the three Democratic Criteria as we saw for the cases of Brazil and 
Argentina, proving that the judicial review of constitutional amendments should only be implemented when Judicial Independence is moderate.

For the assessment of the most suitable combination of Institutional Attributes a country should have for adopting the judicial review of constitutional amendments, I created a decision tree (Figure 35, below). In this tree, all possible combinations of Institutional Attributes are laid out, showing twelve possible outcomes. Each outcome is given a Forecasted Success Ratio (FSR) for the adoption of the judicial review of amendments. The FSR is calculated by summing the scores obtained in the fulfilment of Democratic Criteria (expressed by "Met" in Table 1) and dividing by eight (8), which is the maximum number of interactions between Institutional Attributes and Democratic Criteria. We could think that the maximum number of interactions is nine (9), given that we have three (3) Institutional Attributes and three (3) Democratic Criteria $(3 \times 3=9)$, however our findings showed that Legitimacy does not have a direct impact on the Possibility of Overrides and Backlashes ("Little interaction" on Table 1), which reduces the maximum number of interactions to eight (8).

The Forecasted Success of Judicial Review of Constitutional Amendments Decision Tree (Figure 35) shows all the possible combinations of Institutional Attributes in a country, with their Forecasted Success Ratio (FSR) obtained through the fulfilment of Democratic Criteria. 


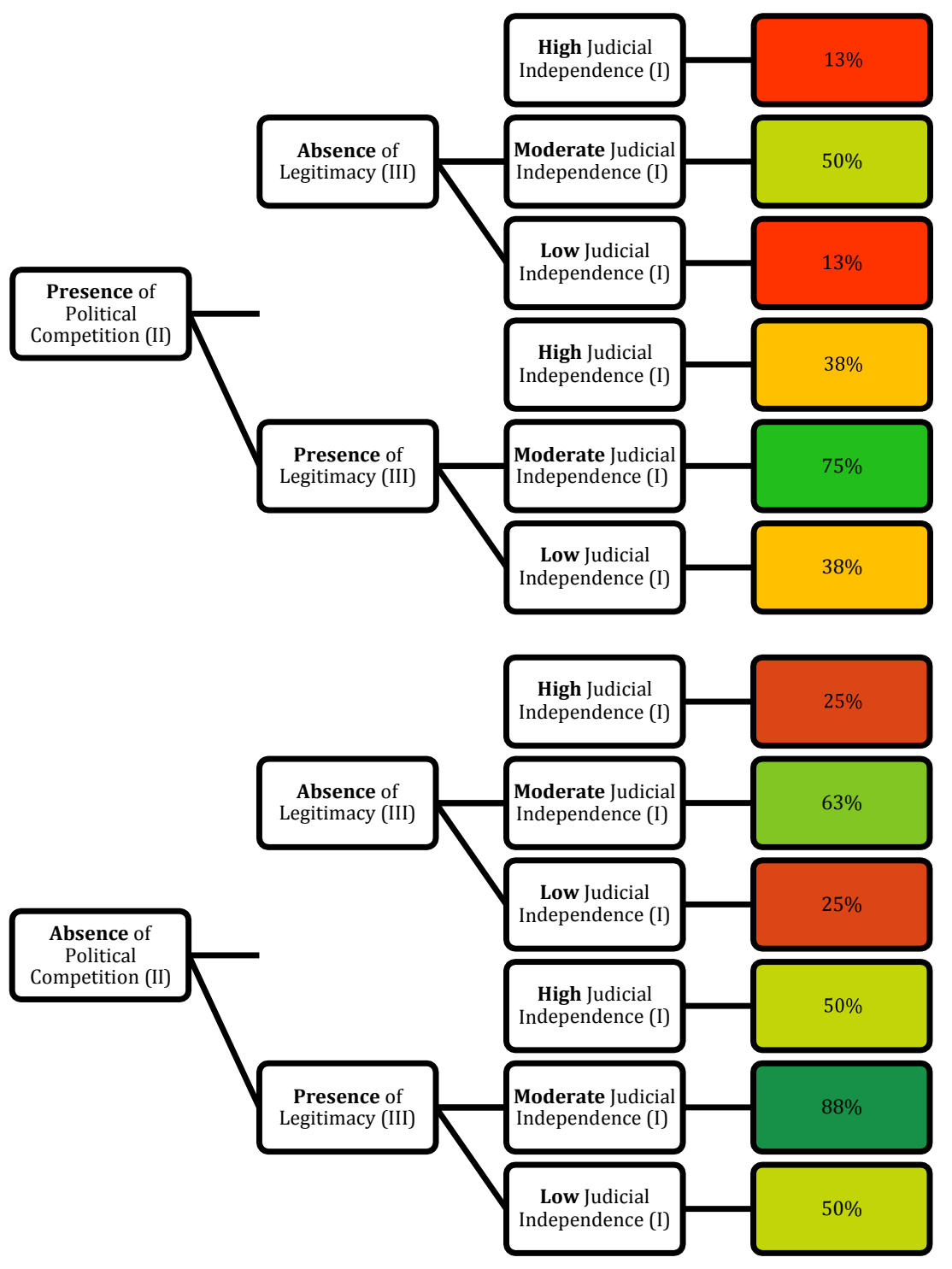

Figure 35. Forecasted Success of Judicial Review of Constitutional Amendments Decision Tree.

This decision tree allows us to assess whether the judicial review of constitutional amendments enhances democracy and should therefore be adopted. We can observe that the Forecasted Success Ratios (FSR) go from 13\% in the worst-case scenario, to $88 \%$ in the best one. The best combination of Institutional Attributes for this power to be granted to the Courts is when there is an absence of Political Competition, the presence of Legitimacy and a moderate level of Judicial Independence, with an FSR of $88 \%$. Our analysis shows that this combination allows the Court to check the concentrated power 
of the elected bodies while holding popular support for these actions. The court would also protect itself from abuses of other actors while the circumstances would prevent judicial over-empowerment.

On the other hand, the worst-case scenarios show a combination of presence of Political Competition, an absence of Legitimacy and excessive or lacking sufficient Judicial Independence, with an FSR of 13\%. In these cases, the court's decision to strike down a constitutional amendment is opposing a political decision that is the fruit of a consensus between several political groups without holding popular support. These two, combined with an excessively high level of Judicial Independence would create an unaccountable court. If combined with low levels of Judicial Independence, it would be a case of impossibility of this power of striking down the amendment to be exerted democratically, given that the power would be captured by other actors and would not effectively belong to the court.

There are twelve different combinations in the decision tree, showing how the presence or absence of Institutional Attributes can have gradually diverse effects on the democratic quality of the judicial review of amendments. This decision tree is intended to guide constitution practitioners to decide on the adoption of the judicial review of amendments. In extreme cases, where the FSR is extremely low, the recommendation would be not to grant justices with the power to review constitutional amendments. On the other hand, when the FSR is significantly high, it is suggested to adopt this kind of judicial review. For the cases in between, with an average FSR, the answer could be the adoption of a formal review of constitutional amendments, instead of substantial. This would allow the court to review the compliance with all the procedures required for enacting an amendment and therefore changing the constitution, but without endangering the checks and balances dynamics. 
It is important to consider that the model has its limitations. I only considered three Institutional Attributes and three Democratic Criteria, which I thought to be the most relevant for the judicial review of constitutional amendments following the rational choice theory. However, we could answer the research question by enriching our model with other inputs, such as the adoption of or other variables to the analysis. For instance, variables related to constitutions (constitutional rigidity, length of the constitution, what subjects are formally constitutional), to the judicial career and justice's background (if tenure is granted, if justices were judges, academics or politicans), to judicial decision-making procedures (quorum to strike down an amendment, if decisions may contain abstract provisions replacing the content of the amendments struck down), or even related to the psychology and socialization of justices (with which groups they interact, how their perceive their institutional role and mission). Other theories may also help us enriching the understanding on the subject, by selection, e.g., an ideational, historical or sociological approach to the research question. In any case, the dissertation aims to bring a contribution to the study of constitutional amendments and assess the role of the Judiciary in the institutional dynamics. 


\section{REFERENCES}

Abregú, Martin and Christian Courtis (1998). "Perspectivas y posibilidades del amicus curiae en el derecho argentino". La aplicación de los Tratados sobre Derechos Humanos por los Tribunales Locales, Martin Abregú and Chirstian Courtis (eds.), Buenos Aires: del Puerto.

Albert, Richard (2009). "Nonconstitutional Constitutional Amendments". Canadian Journal of Law and Jurisprudence 22.

Almeida, Eloísa Machado de (2016). "Amicus Curiae no Supremo Tribunal Federal". Ph.D. Dissertation, Faculty of Law, University of São Paulo.

Arguelhes, Diego Werneck (2014). “Old Courts, New Beginnings: Judicial Continuity and Constitutional Transformation in Argentina and Brazil". JSD Dissertation, Yale Law School.

Arguelhes, Diego Werneck and Ivar Hartmann (2017). “Timing Control Without Docket Control: How Individual Justices Shape the Brazilian Supreme Court's Agenda". Journal of Law and Courts 5, n. 1 (Spring).

Arguelhes, Diego Werneck and Ribeiro, Leandro Molhano. (2018). Ministrocracia: O Supremo Tribunal individual e o processo democrático brasileiro. Novos estud. CEBRAP [online]. 37(1).

Bailey, A. Michael and Maltzman, Forrest. (2011). The Constrained Court: Law, Politics, and the Decisions Justices Make. Princeton: Princeton University Press.

Barroso, Luis Roberto (2018). “Contramajoritário, Representativo e Iluminista: Os Papeis dos Tribunais Constitucionais nas Democracias Contemporâneas". Revista Direito E Praxis, v. 9, n. 4.

Baum, Lawrence. (2009). The Puzzle of Judicial Behavior. Ann Arbor: University of Michigan Press. 
Bejar, Trilce Oblitas (2015). “Party System Fragmentation and Democratic Representation in Peru, 1980-2011". Master Thesis, Faculty of Social and Behavioural Sciences, Institute of Political Science, Leiden University.

Benítez-R, Vincente (2017). "Judicial Review of Constitutional Amendments in Times of Peace: The Colombian Case". IACL-AIDC Blog, April 26, 2017.

Benvindo, Juliano Zaiden and Alexandre Araújo Costa (2014). “A Quem Interessa o Controle de Constitucionalidade: O Descompasso Entre Teoria e Prática na Defesa dos Direitos Fundamentais". Working Paper, University of Brasilia.

Benvindo, Juliano Zaiden. (2018). "Brazil in the Context of the Debate Over Unamendability in Latin America". In An Unconstitutional Constitution? Unamendability in Constitutional Democracies, eds. Richard Albert and Bertil Emrah Oder, pp. 345-364. Springer International Publishing.

Bernal-Pulido, Carlos (2013). "Unconstitutional Constitutional Amendments in the case study of Colombia: An analysis of the justification and meaning of the constitutional replacement doctrine". International Journal of Constitutional Law, v. 11, n. 2, 339-357.

Bickel, Alexander (1986). “The Least Dangerous Branch: The Supreme Court at The Bar of Politics". Yale University Press, 2. Ed.

Bonilla, Daniel (2012). "Towards a Constitutionalism of the Global South". Available at SSRN: https://ssrn.com/abstract=2497585 or http://dx.doi.org/10.2139/ssrn.2497585.

Bonilla, Daniel (ed.). "Constitutionalism of the Global South: The Activist Tribunals of India, South Africa, and Colombia". Cambridge University Press.

Braman, Eileen. (2016). "Law, Politics, and Perception: How Policy Preferences Influence Legal Reasoning". Charlottesville: University of Virginia Press.

Cajas-Sarria, Mario Alberto (2017). “Judicial Review of Constitutional Amendments in Colombia: a political and historical perspective (1955-2016)". The Theory and Practice of Legislation, v. 5, n. 3.

Cepeda-Espinosa, Manuel Jose (2004). "Judicial Activism in a Violent Context: The Origin, Role, and Impact of the Colombian Constitutional Court". 3 Washington University Global Studies Law Rev. 539 
Chavez, Rebecca Bill (2003). "The Construction of the Rule of Law in Argentina: A Tale of Two Provinces". Comparative Politics 35(4), 417.

Chavez, Rebecca Bill (2004). "The Evolution of Judicial Autonomy in Argentina: Establishing the Rule of Law in an Ultrapresidential System". Journal of Latin American Studies, v. 36, n. 3.

Chavez, Rebecca Bill (2007). "The Appointment and Removal Process for Judges in Argentina: The Role of Judicial Councils and Impeachment Juries in Promoting Judicial Independence. Latin American Politics and Society, v. 49, 2.

Chavez, Rebecca Bill, John Ferejohn, and Barry Weintgast (2011). "A Theory of the Politically Independent Judiciary". In Latin American Courts (Gretchen Helmke and Julio Rios-Figueroa eds.). Cambridge University Press.

Cheibub, José Antonio, Zachary Elkins and Tom Ginsburg (2011). “Latin American Presidentialism in Comparative and Historical Perspective". 89 Texas Law Review 1708.

Couto, Cláudio Gonçalves and Rogério Arantes. (2006). “Constituição, Governo e Democracia no Brasil”. Revista Brasileira de Ciências Sociais. 21(61), 41-62.

Dahl, Robert (1957). “Decision-Making in a Democracy: The Supreme Court as a National Policy-Maker". 6 Journal of Public Law 279.

Dargent, Eduardo (2009). “Determinants of Judicial Independence: Lessons from Three 'Cases' of Constitutional Courts in Peru (1982-2007)". Journal of Latin American Studies, v. 41.

Desposato, Scott, Matthew Ingram and Osmar Lannes Jr (2015). Power, Composition, and Decision Making: The Behavioral Consequences of Institutional Reform on Brazil's Supremo Tribunal Federal. "Journal of Law, Economics, and Organization", v. 31, 3.

Dixon, Rosalind. (2011). "Constitutional Amendment Rules: A Comparative Perspective". In eds. Ginsburg, Tom and Dixon, Rosalind. Comparative Constitutional Law. Cheltenham and Northampton: Edward Elgar Publishing. pp: 96-111.

Dworkin, Ronald (1986). “Law's Empire”. Harvard University Press.

Dworkin, Ronald (1987). “What is Equality? Part 4: Political Equality". Harvard University Press. 
Ely, Jon Hart (1980). “Democracy and Distrust”. Harvard University Press.

Epstein, Lee (2015-2016). "Some Thoughts on the Study of Judicial Behavior". William \& Mary Law Review 57: 2017-2054.

Epstein, Lee et al. 2003. "The Political (Science) Context of Judging". Saint Louis University Law Journal 47: 783-817.

Epstein, Lee, and Knight, Jack. (1998). The Choices Justices Make. Washington, DC: CQ Press.

Epstein, Lee, Landes, William M, and Posner, Richard A. (2013). "The Behavior of Federal Judges: A Theoretical and Empirical Study of Rational Choice". Cambridge and London: Harvard University Press.

Eslava, Luis (2009). "Constitutionalization of Rights in Colombia: Establishing a ground for meaningful comparisons". Revista Derecho del Estado, n. 22.

Fallon Jr, Richard (2005). Legitimacy and The Constitution. "Harvard Law Review", v. 118, n. 6: 1787-1853.

Ferejohn, John A. and Rosenbluth, Frances McCall and Shipan, Charles R.. (2007) "Comparative Judicial Politics" In The Oxford Handbook of Comparative Politics. Ed Carles Boix and Susan C. Stokes. Oxford and New York: Oxford University Press. pp: 727-751.

Ferreira, Débora Costa (2018). “De Quem a Corte Quer Ser Amiga? Análise Estratégica do Amicus Curiae". Lumen Juris Editors.

Figueiredo, Argelina and Fernando Limongi (2000). "Presidential Power, Legislative Organisation, and Party Behaviour in the Brazilian Legislature". Comparative Politics v. 32, n. 2.

García-Mansilla, Manuel José (2004), "Separation of Powers Crisis: The Case of Argentina". 32 Georgia Journal of Comparative and International Law 307.

Gibson, James L. and Gregory A. Caldeira (1995). “The Legitimacy of Transnational Legal Institutions: Compliance, Support, and the European Court of Justice". American Journal of Political Science, v. 39, n. 2, pp. 459-489. 
Gibson, James L. and Gregory A. Caldeira (2009). "Citizens, Courts, and Confirmations: Positivity Theory and The Judgments of American People". Princeton: Princeton University Press.

Ginsburg, Tom (2008). "The Global Spread of Judicial Review". Oxford Handbook of Law and Politics (Keith Whittington and Daniel Keleman, eds.).

Ginsburg, Tom and Melton, James. (2015). "Does the constitutional amendment rule matter at all? Amendment cultures and the challenges of measuring amendment difficulty". International Journal of Constitutional Law. 13(3): 686-713.

Gomez, Ileana. "Declaring Unconstitutional a Constitutional Amendment: The Argentine Judiciary Forges Ahead". The University of Miami Inter-American Law Review, v. 31, n. 1 .

Gonzalez, Diego Andres (2017). “The Colombian Constitutional Court: Building Legitimacy in its First Period". Working Paper, Universidad Externado.

Guimarães, Livia Gil (2017). “Audiências Públicas no Supremo Tribunal Federal: discurso, prática e lobby". Master Thesis, Faculty of Law, University of São Paulo. Hall, Matthew E. K, and Daniel Ura (2015). "Judicial Majoritarianism". The Journal of Politics 77, n. 3.

Halmai, Gábor. (2012). “Unconstitutional Constitutional Amendments: Constitutional Courts as Guardians of the Constitution?". Constellations. 19(2): 182-203.

Hamilton, Alexander, James Madison and John Jay (1948). “The Federalist, or The New Constitution". New York: Dutton.

Helmke, Gretchen (2005). “Courts Under Constraints: Judges, Generals and Presidents in Argentina". Cambridge: Cambridge University Press.

Helmke, Gretchen and Julio Rios-Figueroa (2011). "Courts in Latin America". Cambridge University Press.

Hirschl, Ran (2007). “Towards Juristocracy: The Origins and Consequences of the New Constitutionalism. Harvard University Press.

Kapiszeski, Diana. (2010) “How Courts Work: Culture, Institutions, and the Brazilian Supreme Tribunal Federal". In Cultures of Legality: judicialization and Political 
Activism in Latin America. Eds Javier Couso, Alexandra Huneeus and Rachel Sieder. Cambridge: Cambridge University Press.

Kapiszewski, Diana. (2012). "High Courts and Economic Governance in Argentina and Brazil". Cambridge University Press.

Kelsen, Hans. (1967). Pure Theory of Law. Trs. Max Knight. Berkeley and Los Angeles: University of California Press. The Lawbook Exchange edition 2009. p. 351.

Kramer, Larry D. (2005). “The People Themselves: Popular Constitutionalism and Judicial Review". Oxford University Press, 1. ed.

Landau, David (2010). "Political Institutions and Judicial Role in Comparative Constitutional Law". 51 Harvard International Law Journal 319.

Landau, David (2014). “Beyond Judicial Independence: The Construction of Judicial Power in Colombia". Ph.D. Dissertation, School of Arts and Sciences (Department of Government), Harvard University.

Landau, David and Julian Daniel López-Murcia (2009). “Political Institutions and Judicial Role: An Approach in Context, The Case of the Colombian Constitutional Court". Vniversitas, Bogotá (Colombia), v. 119.

Leiras, Marcelo, Agustina Giraudy and Guadalupe Tuñon (2014). “Who Wants an Independent Court? Political Competition and Supreme Court Instability in the Argentine Provinces (1984-2008)". The Journal of Politics, v. 77, n. 1.

Levistky, Steven, and Daniel Ziblatt (2018). “How Democracy Dies”. Washington, DC: Crown.

Levitsky, Steven (1999). "Fujimori and Post-Party Politics in Peru". Journal of Democracy, v. 10, n. 3.

Levitsky, Steven and Maria Victoria Murillo (2011). “The Politics of Institutional Weakness". Penn State University Press.

Lizarazo-Rodrigues, Liliana (2011). "Constitutional Adjudication in Colombia: AvantGarde or Case Law Transplant? A literature review". Estudos Socio-Jurídicos, v. 13, n. 1, pp. 145-182. 
Maveety, Nancy. (2006). The Pioneers of Judicial Behavior. Ann Arbor Michigan: University of Michigan Press.

Mendes, Conrado Hübner (2005). “Judicial Review of Constitutional Amendments in The Brazilian Supreme Court". Florida Journal of International Law, v, 17.

Mendes, Conrado Hübner (2010). “Onze Ilhas”. Op-ed, Folha de São Paulo. February 1 st, 2010.

Mendes, Conrado Hübner (2014). "Constitutional Courts and Deliberative Democracy". Oxford University Press.

Merhof, Katrin (2015). “Building a Bridge Between Reality and the Constitution: The establishment and development of the Colombian Constitutional Court". International Journal of Constitutional Law, v. 13, n. 3, 714-732;

Mohallem, Michael Freitas. (2011). "Immutable Clauses and Judicial Review in India, Brazil and South Africa: Expanding Constitutional Courts' Authority". International Journal of Human Rights. 15(5): 765-786.

Nino, Carlos Santiago (1992). "The Debate over Constitutional Reform in Latin America"16 Fordham International Law Journal 635.

Nunes, Rodrigo (2010). "Ideational origins of progressive judicial activism: The Colombian constitutional court and the right to health". Latin American Politics and Society, 52(3), 67-97.

O'Donnell, Guillermo (2006). “On Informal Institutions, Once Again”. Informal Institutions and Democracy: Lessons from Latin America (Gretchen Helmke and Steven Levistky (eds.).

Oliveira, Fabiane Luci de. (2012). Processo Decisório no Supremo Tribunal Federal: Coalizões e "Panelinhas". “Revista de Sociologia e Política”, v. 20, n. 44, pp. 139-153.

Olson, Mancur. (1965). "The Logic of Collective Action". Cambridge and London: Harvard University Press.

Perea, Juan Francisco (2006). “Of Presidents and Precedents: The Role of Judicial Review in Presidential Election in Peru, Costa Rica, and the United States". Working Paper, University of Florida Levin College of Law. 
Rambourg Jr., Ribamar Cezar (2019). “A Crise na Coalizão e o Impeachment de Dilma Roussef". Master's Thesis in Political Science, University of São Paulo.

Recondo, Felipe (2019). “Os Onze: O STF, seus bastidores e suas crises”. São Paulo: Companhia das Letras.

Recondo, Felipe. (2018). "Tanques e Togas: O STF e a Ditadura Militar". São Paulo: Companhia das Letras.

Rodriguez-Raga, Juan Carlos (2011). “Strategic Prudence in the Colombian Constitutional Court". Ph.D Dissertation, Political Science, University of Pittsburgh.

Roznai, Yaniv. (2017). Unconstitutional Constitutional Amendments. Oxford University Press.

Sadek, Maria Tereza (2004). "Judiciário: Mudanças e Reformas". Estudos Avançados 18(51): 79-101.

Scotti, Valentina Rita. (2018). "Constitutional amendments and constitutional core values: the Brazilian case in a comparative perspective" Revista de Investigações Constitucionais 5(3): 59-76

Segal, A. Jeffrey and Spaeth, J. Harold. (1993). The Supreme Court and the Attitudinal Model. New York: Cambridge University Press.

Segal, A. Jeffrey and Spaeth, J. Harold. (2002). The Supreme Court and the Attitudinal Model Revisited. New York, NY: Cambridge University Press.

Segal, Jeffrey A. 1984. "Predicting Supreme Court Decisions Probabilistically: The Search and Seizure Cases (1962-1981)." American Political Science Review 78: 891-900.

Silva, Virgílio Afonso da (2013). “Deciding Without Deliberating". International Journal of Constitutional Law, v. 11, n. 3, 557-584.

Susan Rose-Ackerman, Diane A. Desierto and Natalia Volosin (2011), “HyperPresidentialism: Separation of Powers without Checks and Balances in Argentina and the Philippines". Yale Faculty Scholarship Series 4155.

The Anti-Federalist Papers (1966). Indianapolis, Cecília Kenyon ed. 
Tiede, Lydia Brashear and Aldo Fernando Ponce (2014). “Evaluating Theories of Decision-making on the Peruvian Constitutional Tribunal". Journal of Politics in Latin America, v. 6, n. 2.

Tommasini, Nicola and da Silva, Roberto Baptista Dias. (2018) “Reflexões Críticas sobre a declaração de inconstitucional de ofício". Revista de Investigações Constitucionais 5(2): 187-208.

Tushnet, Mark (2000). "Taking the Constitution Away From the Courts". Princeton University Press.

Verbitsky, Horacio (1993). “Hacer la Corte: La Construcción de un Poder Absoluto sin Justicia ni Control “. Buenos Aires: Planeta.

Vieira, Oscar Vilhena (2018). “A batalha dos poderes". São Paulo: Cia das Letras.

Vieira, Oscar Vilhena. (2008). “Supremocracia”. Revista Direito Gv. 4(2):441-464.

Waldron, Jeremy (1999). “Law and Disagreement”. Oxford University Press.

Waldron, Jeremy (2006). "The Core of The Case Against Judicial Review". 115 Yale Law Journal

Warren, Roger K. (2003). “The Importance of Judicial Independence and Accountability". Washington, DC: National Center for State Courts.

Yap, Po Jen. (2015). "The Conundrum of Unconstitutional Constitutional Amendments" Global Constitutionalism 4(1): 114- 136. 

(1988-2018)

\begin{tabular}{|c|c|c|c|c|c|c|c|c|c|c|c|}
\hline ADI № & Filing Date & Amendment & $\begin{array}{c}\text { Individual } \\
\text { Preliminary } \\
\text { Decisions }\end{array}$ & $\begin{array}{c}\text { Collegiate } \\
\text { Preliminary } \\
\text { Decisions }\end{array}$ & $\begin{array}{c}\text { Final } \\
\text { Decisions } \\
\text { Confirming } \\
\text { Preliminary } \\
\text { Decisions }\end{array}$ & $\begin{array}{c}\text { Amicus } \\
\text { Curiae } \\
\text { Petitions }\end{array}$ & $\begin{array}{c}\text { Senate } \\
\text { Petitions }\end{array}$ & $\begin{array}{c}\text { House of } \\
\text { Repr. } \\
\text { Petitions }\end{array}$ & $\begin{array}{c}\text { Shifting } \\
\text { Votes }\end{array}$ & $\begin{array}{c}\text { "Pedido } \\
\text { de Vista" }\end{array}$ & $\begin{array}{c}\text { Pending } \\
\text { Cases }\end{array}$ \\
\hline 829 & 1993 & CA 2/92 & & & & & $x$ & & & & \\
\hline 830 & 1993 & CA $2 / 92$ & & & & & & $x$ & & & \\
\hline 833 & 1993 & CA 2/92 & & $x$ & $x$ & & & & & $x$ & \\
\hline 913 & 1993 & CA $3 / 93$ & & & & & & & & & \\
\hline 926 & 1993 & CA 3/93 & & $x$ & & & $x$ & & & & \\
\hline 939 & 1993 & CA $3 / 93$ & & $x$ & $x$ & & $x$ & $x$ & & & \\
\hline 949 & 1993 & CA $3 / 93$ & & $x$ & $x$ & & & & & & \\
\hline 1420 & 1996 & CA $10 / 96$ & & $x$ & $x$ & & $x$ & & & & \\
\hline 1497 & 1996 & CA $12 / 96$ & & $x$ & $x$ & & & & & $x$ & \\
\hline 1501 & 1996 & CA $12 / 96$ & & $\mathrm{x}$ & $x$ & & & & & $x$ & \\
\hline 1749 & 1997 & CA $14 / 96$ & & $x$ & & & $x$ & $x$ & & & \\
\hline 1805 & 1998 & CA 16/97 & & $x$ & & & $x$ & $\mathrm{x}$ & & & $x$ \\
\hline 1946 & 1999 & CA 20/98 & & $x$ & $x$ & & $x$ & $x$ & & & \\
\hline 2024 & 1999 & CA 20/99 & & $x$ & $x$ & $x$ & $x$ & & & & \\
\hline 2027 & 1999 & CA $21 / 99$ & & $x$ & & & $x$ & & & & \\
\hline 2031 & 1999 & CA $21 / 99$ & & $x$ & $x$ & & $x$ & & & & \\
\hline 2047 & 1999 & CA 19/98 & & & & & & & & & \\
\hline 2096 & 1999 & CA 20/98 & & & & & $x$ & $x$ & & & $x$ \\
\hline 2135 & 2000 & CA 19/98 & & & & $x$ & $x$ & & & $x$ & $x$ \\
\hline 2159 & 2000 & CA 19/98 & & & & & $x$ & $x$ & & & \\
\hline 2242 & 2000 & CA 20/98 & & & & & $x$ & & & & $x$ \\
\hline 2356 & 2000 & CA $30 / 00$ & & $x$ & & & $x$ & & & $x$ & $x$ \\
\hline 2362 & 2000 & CA $30 / 00$ & & $x$ & & & & & & $x$ & \\
\hline 2395 & 2001 & CA $15 / 98$ & & & & & $x$ & & & & \\
\hline 2666 & 2002 & CA $37 / 02$ & & & & & $x$ & & & & \\
\hline 2673 & 2002 & CA $37 / 02$ & & & & & $x$ & & & & \\
\hline 2732 & 2002 & CA $29 / 00$ & & & & $x$ & $x$ & & & & \\
\hline 2760 & 2002 & CA 20/98 & & & & & & & & & \\
\hline 2883 & 2003 & CA 20/98 & & & & & $x$ & & & & \\
\hline 3099 & 2003 & CA 41/03 & & & & $x$ & $x$ & & & & \\
\hline
\end{tabular}




\begin{tabular}{|c|c|c|c|c|c|c|c|c|c|c|c|}
\hline 3104 & 2003 & CA 41/03 & & & & $x$ & $x$ & & & & \\
\hline 3105 & 2003 & CA $41 / 03$ & & & & $x$ & $x$ & & & $x$ & \\
\hline 3128 & 2004 & CA $41 / 03$ & & & & $x$ & $x$ & & & $x$ & \\
\hline 3133 & 2004 & CA $41 / 03$ & & & & $x$ & & & & $x$ & $x$ \\
\hline 3138 & 2004 & CA 41/03 & & & & $x$ & $x$ & & & & \\
\hline 3143 & 2004 & CA 41/03 & & & & $x$ & $x$ & & & $x$ & $x$ \\
\hline 3172 & 2004 & CA $41 / 03$ & & & & $x$ & & & & & \\
\hline 3184 & 2004 & CA 41/03 & & & & $x$ & & & & $x$ & $x$ \\
\hline 3291 & 2004 & CA 41/03 & & & & & & & & & \\
\hline 3297 & 2004 & CA 41/03 & & & & $\mathrm{x}$ & $\mathrm{x}$ & & & & $x$ \\
\hline 3308 & 2004 & CA $41 / 03 ; 20 / 98$ & & & & $\mathrm{x}$ & $\mathrm{x}$ & $x$ & & & $x$ \\
\hline 3363 & 2004 & CA $41 / 03 ; 20 / 98$ & & & & $\mathrm{x}$ & $\mathrm{x}$ & & & & $x$ \\
\hline 3367 & 2004 & CA $45 / 04$ & & & & & $\mathrm{x}$ & & & & \\
\hline 3395 & 2005 & CA $45 / 04$ & $x$ & $x$ & & & $x$ & & & & $x$ \\
\hline 3472 & 2005 & CA $45 / 04$ & & $x$ & & & $x$ & & & & \\
\hline 3529 & 2005 & CA $45 / 04$ & & & & & & & & & \\
\hline 3684 & 2006 & CA $45 / 04$ & & $x$ & & $x$ & $\mathrm{x}$ & $\mathrm{x}$ & & & $x$ \\
\hline 3685 & 2006 & CA 52/06 & & & & $x$ & $\mathrm{x}$ & & & & \\
\hline 3686 & 2006 & CA 52/06 & & & & & & & & & \\
\hline 3843 & 2007 & CA $45 / 04$ & & & & & $x$ & & & & \\
\hline 3854 & 2007 & CA $41 / 03$ & & $x$ & & & & & & & $x$ \\
\hline 3855 & 2007 & CA 41/03 & & & & & $x$ & & & & $x$ \\
\hline 3867 & 2007 & CA $41 / 03$ & & & & & $x$ & & & & \\
\hline 3872 & 2007 & CA $41 / 03$ & & & & $x$ & $x$ & & & & $x$ \\
\hline 3998 & 2007 & CA 41/03; 20/98 & & & & $\mathrm{x}$ & $\mathrm{x}$ & & & & $x$ \\
\hline 4014 & 2008 & CA 41/03 & & & & & $\mathrm{x}$ & $x$ & & & $x$ \\
\hline 4307 & 2009 & CA 58/09 & $x$ & & $x$ & $x$ & & & & & \\
\hline 4357 & 2009 & CA 62/09 & & & & $x$ & $x$ & $x$ & $x$ & $x$ & \\
\hline 4372 & 2010 & CA 62/09 & $x$ & & $x$ & $x$ & $x$ & $x$ & & & \\
\hline 4400 & 2010 & CA 62/09 & & & & $x$ & $x$ & $x$ & & & \\
\hline 4425 & 2010 & CA 62/09 & & & & $x$ & $x$ & $x$ & $x$ & $x$ & \\
\hline 4802 & 2012 & CA 41/03; 20/98 & & & & & & & & & $x$ \\
\hline 4803 & 2012 & CA 41/03; 20/98 & & & & & & & & & $x$ \\
\hline 4885 & 2012 & CA $41 / 03$ & & & & $x$ & $x$ & $x$ & & & $x$ \\
\hline 4887 & 2012 & CA 41/03 & & & & $x$ & $x$ & & & & $x$ \\
\hline 4888 & 2012 & CA 41/03 & & & & $x$ & $x$ & & & & $x$ \\
\hline 4889 & 2012 & CA 20/98 & & & & $x$ & & & & & $x$ \\
\hline 5017 & 2013 & CA $73 / 13$ & $x$ & & & $x$ & & & & & $x$ \\
\hline 5296 & 2015 & CA $74 / 13$ & & $x$ & & $x$ & $x$ & $x$ & & $x$ & $x$ \\
\hline 5316 & 2015 & CA 88/15 & & $x$ & & $x$ & $x$ & $x$ & & & $x$ \\
\hline 5497 & 2016 & CA 91/16 & & & & $x$ & $x$ & $x$ & & & $x$ \\
\hline 5595 & 2016 & CA 86/15 & $x$ & & & $x$ & $x$ & & & & $x$ \\
\hline 5633 & 2016 & CA 95/16 & & & & $x$ & $x$ & $x$ & & & $x$ \\
\hline \multicolumn{2}{|c|}{ Total } & $\begin{array}{c}\text { Deliberation } \\
\text { Characteristics }\end{array}$ & $\begin{array}{l}\text { Individual } \\
\text { Preliminary } \\
\text { Decisions }\end{array}$ & $\begin{array}{l}\text { Collegiate } \\
\text { Preliminary } \\
\text { Decisions }\end{array}$ & \begin{tabular}{l}
\multicolumn{1}{c}{ Final } \\
Decisions \\
Confirming \\
Preliminary \\
Decisions
\end{tabular} & $\begin{array}{l}\text { Amicus } \\
\text { Curiae } \\
\text { Petitions }\end{array}$ & $\begin{array}{c}\text { Senate } \\
\text { Petitions }\end{array}$ & $\begin{array}{c}\text { House of } \\
\text { Repr. } \\
\text { Petitions }\end{array}$ & $\begin{array}{c}\text { Shifting } \\
\text { Votes }\end{array}$ & $\begin{array}{l}\text { "Pedido } \\
\text { de Vista" }\end{array}$ & $\begin{array}{c}\text { Pending } \\
\text { Cases }\end{array}$ \\
\hline \multicolumn{2}{|c|}{73} & $\begin{array}{l}\text { Number } \\
\text { of Cases }\end{array}$ & 5 & 21 & 11 & 34 & 52 & 19 & 2 & 14 & 30 \\
\hline & & $\%$ & $6.8 \%$ & $28.8 \%$ & $15.1 \%$ & $46.6 \%$ & $71.2 \%$ & $26.0 \%$ & $2.7 \%$ & $19.2 \%$ & $41.1 \%$ \\
\hline
\end{tabular}




\section{ANNEX 2 - BRAZILIAN SUPREME COURT DECISIONS ("ADIs") REVIEWING CONSTITUTIONAL AMENDMENTS}

FILES: Number of the ADI; Plaintiffs; Defendants; A) Amendment being questioned; B) Subject being discussed; C) Amici Curiae petitions; D) Authorities petitions; E) Presence or absence of preliminary rulings ("liminares"); F) Final decisions; G) Presence or absence of "pedidos de vista" and dates; H) Presence or absence of shifting votes.

ADI 5633 - Associação Nacional dos Magistrados Brasileiros, Associação Nacional dos Magistrados da Justiça do Trabalho, Associação dos Juízes Federais vs. National Congress. A) Amendment being questioned: CA 95/2016 (articles 101 a 104, ADCT); B) Subject: Public spending limits ("Teto dos Gastos"), arguing violation of the separation of powers and that the participation of the Judiciary on the amendment process in this case should be mandatory; C) Amici Curiae petitions: União Nacional dos Juízes Federais do Brasil, Sindicato União dos Servidores Públicos do Judiciário do Estado de São Paulo e Defensoria Pública da União; D) Authorities petitions: Senate; House of Representatives; Attorney-General; Solicitor-General; E) No preliminary ruling (Justice Rosa Weber; art. 10, Act 9868/99). F) No final decision; G) No "Pedido de Vista"; H) No shifting votes.

ADI 5595 - Solicitor-General of the Republic vs. National Congress. A) Amendment being questioned: CA 86/2015 (articles 2o e 3o, CA 86/2015); B) Subject: Public Budget ("Orçamento Impositivo"), arguing the reduction of funding for health services; C) Amici Curiae Petitions: Associação Nacional do Ministério Público de Contas, Instituto de Direito Sanitário Aplicado, Central Única dos Trabalhadores, Instituto de Direito Sanitário Aplicado; D) Authorities Petitions: Senate; Attorney-General; E) Positive preliminar ruling (Individual - Justice Ricardo Lewandowski). F) No final decision (preliminary ruling still in effect); G) No "Pedido de Vista". H) No shifting votes.

ADI 5497 - Partido Trabalhista Nacional - PTN vs. National Congress. A) Amendment being questioned: CA 91/2016 (article 1丷, CA 91/2016); B) Subject: Distribution of TV and 
Radio time in electoral campaigns ("Janela Partidária"). C) Amici Curiae Petitions: Partido da República - PR; Partido da Mulher Brasileira - PMB; Partido Republicano Progressista - PRP; Partido Progressista - PP; Partido Humanista da Solidariedade PHS; D) Authorities Petitions: Senate; House of Representatives (only formal analysis); Attorney-General; Solicitor-General; E) No preliminary rulings (Dias Toffoli, art. 12, Act 9869/99), however there is a mention to the lack of plausibility of the request; F) No final decision; G) No "Pedido de Vista"; H) No shifting votes.

ADI 5316 - Associação Nacional dos Magistrados Brasileiros, Associação Nacional dos Magistrados da Justiça do Trabalho, Associação dos Juízes Federal vs. National Congress. A) Amendments being questioned: CA 88/2015 (art. 2º, CA 88/2015 - art. 100, $A D C T$, Constitution). B) Subject: Requirement for a second Senate confirmation for judges who reach the age of 70 years old ("PEC da Bengala"). C) Amici Curiae Petitions: Associação Nacional de Desembargadores; D) Authorities Petitions: Senate; House of Representatives (only formal analysis); Attorney-General; Solicitor-General; E) Positive Preliminary ruling (Collegiate - Plenary); F) No final decision; G) No "Pedido de Vista"; H) No shifting votes.

ADI 5296 - President of the Republic (Dilma Rousseff) X National Congress. A) Amendment being questioned: CA 74/2013 (full text). B) Subject: Financial Autonomy of the Federal Public Defenders, arguing that Congress had invaded the President's competence to decide about the legal regime of public servants; C) Amici Curiae Petitions: Associação Nacional dos Defensores Públicos Federais, Defensoria Pública da União, União dos Advogados Públicos Federais do Brasil, Partido Popular Socialista PPS, Sindicato Nacional dos Procuradores da Fazenda Nacional; Defensoria Pública do Distrito Federal, Associação Nacional dos Defensores Públicos, SOLIDARIEDADE, Associação Nacional dos Advogados da União, Estado de São Paulo, Defensoria Pública da União, Estado do Espírito Santo, Estado do Acre, Defensoria Pública do Estado do Espírito Santo, Estado do Amazonas, Estado de Roraima, Defensoria Pública do Estado de São Paulo; D) Authorities Petitions: Senate; House of Representatives; AttorneyGeneral; Solicitor-General; E) Negative preliminary ruling (Collegiate - Plenary); F) No final decision; G) "Pedidos de Vista": Justice Edson Fachin (Requested: 08/10/2015; Returned: 13/10/2015; 5 days); Justice Dias Toffoli (Requested: 22/10/2015; Returned: 18/12/2015; 57 days); H) No shifting votes. 
ADI 5017 - Associação Nacional Dos Procuradores Federais vs. National Congress. A) Amendment being questioned: CA 73/2013 (full text). B) Subject: Creation of new Federal Court of Appeals (Tribunais Regionais Federais). C) Amici Curiae Petitions: Conselho Federal da Ordem dos Advogados do Brasil, Associação Nacional dos Magistrados Brasileiros, Estado do Paraná, Associação dos Juízes Feder ais do Brasil, Estado de Minas Gerais, Associação Paranaense de Juízes Federais, Associação Nacional dos Procuradores da República, Associação Nacional dos Procuradores Municipais, Município de Salvador, OAB Minas Gerais, OAB Bahia, Confederação dos Trabalhadores no Serviço Público Federal e Federação dos Trabalhadores no Serviço Público Federal, Rafael Costa Monteiro; D) Authorities Petitions: Attorney-General; Solicitor-General; E) Positive preliminary ruling (Individual - Chief Justice Joaquim Barbosa); F) No final decisions; G) No "Pedido de Vista"; H) No shifting votes.

ADI 4889 - Partido Socialismo e Liberdade vs. National Congress. A) Amendment being questioned: CA 41/2003 (full text). B) Subject: Reform of the Social Security System (vote-buying in Congress to approve the amendment). C) Amicus Curiae Petitions: Confederação dos Trabalhadores no Serviço Público Federal, Sindicato Nacional dos Servidores Federais da Educação Básica, Profissional e Tecnológica; D) Authorities Petitions: Attorney-General; Solicitor-General; E) No preliminary rulings; F) No final decision; G) No "Pedido de Vista"; H) No shifting votes.

ADI 4888 - Confederação Dos Servidores Públicos Do Brasil vs. National Congress. A) Amendment being questioned: CA 41/2003 (articles $1^{\circ}$ and $4^{\circ}$, CA 41/2003). B) Subject: Subject: Reform of the Social Security System (vote-buying in Congress to approve the amendment). C) Amicus Curiae Petitions: Sindicato Nacional dos Auditores-Fiscais da Receita Federal do Brasil, Sindicato Nacional dos Servidores Federais Autárquicos nos Entes de Formulação, Promoção e Fiscalização da Política da Moeda e do Crédito, Sindicato dos Agentes Fiscais de Rendas do Estado de São Paulo; D) Authorities Petitions: Senate; Attorney-General; Solicitor-General; E) No preliminar ruling; F) No final decision; ; G) No "Pedido de Vista"; H) No shifting votes.

ADI 4887 - Associação Dos Delegados De Polícia Do Brasil vs. National Congress. A) Amendment being questioned: CA 41/2003 (articles 1 and 4, CA 41/2003). B) Subject: 
Reform of the Social Security System (vote-buying in Congress to approve the amendment); C) Amicus Curiae Petitions: Sindicato Nacional dos Auditores-Fiscais da Receita Federal do Brasil, Sindicato dos Auditores Fiscais da Receita Estadual do Rio de Janeiro, Sindicato Nacional dos Servidores Federais Autárquicos nos Entes de Formulação, Promoção e Fiscalização da Política da Moeda e do Crédito; D) Authorities Petitions: Senate; Attorney-General; E) No preliminar ruling; F) No final decision; ; G) No "Pedido de Vista"; H) No shifting votes.

ADI 4885 - Associação Dos Magistrados Brasileiros, Associação Nacional Dos Magistrados Da Justiça Do Trabalho vs. National Congress. A) Amendment being questioned: CA 41/2003 (article 1, CA 41/2003) B) Subject: Reform of the Social Security System (vote-buying in Congress to approve the amendment); C) Amicus Curiae Petitions: Sindicato Nacional dos Auditores-Fiscais da Receita Federal do Brasil, Estado do Rio Grande do Sul; D) Authorities Petitions: Senate; House of Representatives; Attorney-General; Solicitor-General; E) Negative preliminar ruling (Collegiate Plenary); F) No final decision ; G) No "Pedido de Vista"; H) No shifting votes.

ADI 4803 - Associação Dos Magistrados Brasileiros vs. National Congress. Joint processing (ADIs 3308, 3363, 4802, 4802). A) Amendment being questioned: CA 20/1998 and CA 41/2003 (article 1, CA 20/1998; §§ 2 e 3, article 1, CA 41/2003). B) Subject: Social Security System for Judges; C) No Amicus Curiae petitions; D) No authorities petitions; E) No preliminary ruling; F) No final decision; G) No "Pedido de Vista"; H) No shifting votes.

ADI 4802 - Associação Dos Magistrados Brasileiros vs. National Congress. Joint processing (ADIs 3308, 3363, 4802, 4802). A) Amendment being questioned: CA 20/1998 and CA 41/2003 (article 1, CA 20/1998; §§ 2 e 3, article 1, CA 41/2003). B) Subject: Social Security System for Judges; C) No Amicus Curiae petitions; D) No authorities petitions; E) No preliminary ruling; F) No final decision; G) No "Pedido de Vista"; H) No shifting votes.

ADI 4425 - Confederação Nacional Das Indústrias vs. National Congress. Joint processing (ADIs 4357, 4372, 4400 e 4425) A) Amendment being questioned: CA 62/2009 (articles 1, 2, 3, 4, and 6, CA 62/2009); B) Subject: Public Payment Orders ("Precatórios"); 
C) Amicus Curiae petitions: Estado do Pará, Conselho Federal da OAB; D) Authorities petitions: Senate; House of Representatives (only formal analysis); Attorney-General; Solicitor-General; E) No preliminary ruling; F) Final decision for the partial unconstitutionality of the amendment; G) "Pedidos de Vista": Justice Luiz Fux (Required: 6/10/2011; Returned 08/02/2013; 491 days); Justice Luis Roberto Barroso (Required: 24/10/2013; Returned: 06/02/2014, 105 days); Justice Dias Toffoli (Required: 19/03/2014; Returned: 02/03/2015, 348 days); H) Shifting votes: Justices Luiz Fux, Luis Roberto Barroso, Dias Toffoli and Gilmar Mendes.

ADI 4400 - Associação Nacional Dos Magistrados Da Justiça Do Trabalho vs. National Congress. Joint processing (ADIs 4357, 4372, 4400 e 4425). A) Amendment being questioned: CA 62/2009 (article 100, § 9, 10, 12, and 15, Federal Constitution); B) Subject: Public Payment Orders ("Precatórios"); C) Amicus Curiae petitions; Estado do Pará; D) Authorities petitions: Senate, House of Representatives (only formal analysis), Attorney-General; Solicitor-General; E) No preliminary ruling; F) Final decision (extinct for formal reasons); G) No "Pedido de Vista"; H) No shifting votes.

ADI 4372 - Associação Nacional Dos Magistrados Estaduais vs. National Congress. Joint processing (ADIs 4357, 4372, 4400 e 4425). A) Amendment being questioned: CA 62/2009 (articles 100, §§ 2, 9, 10, and 12, Federal Constitution, and article 97, §§ 1, 2, 6, 7, 8, 9, and 16, ADCT; B) Subject: Public Payment Orders ("Precatórios"); C) Amicus Curiae petitions: Conselho Federal da OAB, Município de Belém, Estado do Pará; D) Authorities petitions: Senate; House of Representatives (only formal analysis); Attorney-General; E) Positive preliminary ruling (Individual - Justice Ayres Britto); F) Final decision (extinct for formal reasons); G) No "Pedido de Vista"; H) No shifting votes.

ADI 4357 - Associação Dos Magistrados Brasileiros vs. National Congress. Joint processing (ADIs 4357, 4372, 4400 e 4425). A) Amendment being questioned: CA 62/2009 (full text). B) Subject: Public Payment Orders ("Precatórios"); C) Amicus Curiae petitions: Sindicato dos Especialistas de Educação do Ensino Público Municipal, Frente Nacional de Prefeitos, Fórum de Professores das Instituições Federais de Ensino Superior, Estado do Pará, Associação Nacional para Defesa da Cidadania, Meio Ambiente e Democracia, Município de Porto Alegre; D) Authorities petitions: Senate; House of Representatives (only formal analysis); Attorney-General; Solicitor-General; E) 
No preliminary ruling; F) Final decision for the partial unconstitutionality of the amendment; G) "Pedidos de Vista": Justice Luiz Fux (Required: 6/10/2011; Returned 08/02/2013; 491 days); Justice Luis Roberto Barroso (Required: 24/10/2013; Returned: 06/02/2014, 105 days); Justice Dias Toffoli (Required: 19/03/2014; Returned: 02/03/2015, 348 days); H) Shifting votes: Justices Luiz Fux, Luis Roberto Barroso, Dias Toffoli and Gilmar Mendes.

\begin{abstract}
ADI 4307 - Solicitor-General of the Republic vs. National Congress. A) Amendment being questioned: CA 58/2009 (article 3, I, CA 58/2009); B) Subject: Electoral Reform (principle of anteriority); C) Amicus Curiae petitions: Geraldo Sales Ferreira, Idenor Machado, Juarez de Oliveira, Jucemar Almeida Arnal, Laudir Antônio Munaretto, Valter Ribeiro Hora (deputy councilmen), Partido Humanista da Solidariedade - PHS, Mario Heringer (congressman), Associação Brasileira das Câmaras Municipais, Diretório Municipal do DEM de Santa Cruz do Sul - RS, Admilson Rossi (deputy councilman); D) Authorities petitions: Attorney-General; E) Positive preliminar ruling (Individual - Justice Carmen Lúcia; confirmed by the plenary); F) Final decision (confirmed the preliminary ruling); G) No "Pedido de Vista"; H) No shifting votes.
\end{abstract}

ADI 4014 - Associação Nacional Dos Magistrados Estaduais vs. National Congress. Joint Processing (ADIs 4014, 3855, 3854, 3872). A) Amendment being questioned: CA 41/2003 (article 1, CA 41/2003); B) Subject: Judges' subsidies; C) No Amicus Curiae petitions; D) Authorities petitions: Senate; House of Representatives (only formal analysis); Attorney-General; National Council of Justice; E) No preliminary ruling; F) No final decision; G) No "Pedido de Vista"; H) No shifting votes.

ADI 3998 - Associação Nacional Dos Juízes Federais vs. National Congress. A) Amendment being questioned: CA 20/1998 and CA 41/2003; B) Subject: Judges' Social Security Sistem ("Reforma da Previdência"); C) Amicus Curiae petitions: Associação Paulista de Magistrados, Associação dos Magistrados Mineiros, Associação dos Juízes do Rio Grande do Sul, Associação Nacional dos Magistrados Estaduais; D) Authorities petitions: Senate; Attorney-General; Solicitor-General; E) No preliminary ruling; F) No final decision; G) No "Pedido de Vista"; H) No shifting votes. 
ADI 3872 - Partido Trabalhista Brasileiro - PTB vs. National Congress. Joint processing (ADIs 3855, 3854, 3872). A) Amendment being questioned: CA 41/2003 (article 1, C 41/2003); B) Subject: Public Servants' subsidies ("Reforma da Previdência"); C) Amicus Curiae petitions: Sindicato dos Servidores da Fazenda do Estado da Bahia, Sindicato dos Fiscais de Rendas do Estado do Rio de Janeiro, Sindicato dos Auditores Fiscais da Fazenda Estadual do Estado do Piauí, Sindicato dos Fiscais de Tributos Estaduais de Mato Grosso, Sindicato dos Agentes Fiscais de Rendas do Estado de São Paulo, Sindicato do Fisco do Estado de Alagoas; D) Authorities petitions: Senate; AttorneyGeneral; Solicitor-General; E) No preliminary ruling; F) No final decision; G) No "Pedido de Vista"; H) No shifting votes.

ADI 3867 - Partido Democrático Trabalhista - PDT vs. National Congress. A) Amendment being questioned: CA 19/1998 and CA 41/2003 (articles 3 and 5, CA 19/1998, articles 8 and 9, CA 41/2003; B) Subject: Social Security Reform ("Reforma da Previdência"); C) No Amicus Curiae petitions; D) Authorities petitions: Senate; AttorneyGeneral; Solicitor-General; E) No preliminary ruling; F) Negative final decision; G) No "Pedido de Vista"; H) No shifting votes.

ADI 3855 - Associação Dos Delegados De Polícia Do Brasil vs. National Congress. Joint processing (ADIs 4014, 3855, 3854, 3872). A) Amendment being questioned: CA 41/2003 (art. 19); B) Subject: Public Servants' Salary Limits; C) No Amicus Curiae petitions; D) Authorities petitions: Senate; Attorney-General; Solicitor-General; E) No preliminary ruling; F) No final decision; G) No "Pedido de Vista"; H) No shifting votes.

ADI 3854 - Associação Dos Magistrados Brasileiros vs. National Congress. Joint processing (ADIs 4014, 3855, 3854, 3872). A) Amendment being questioned: CA 41/2003 (article 1, CA 41/2003); B) Subject: Judges' subsidies ("Reforma da Previdência"); C) No Amicus Curiae petitions; D) No authorities petitions; E) Positive preliminary ruling (Collegiate - plenary); F) No final decision; G) No "Pedido de Vista"; H) No shifting votes.

ADI 3843 - Associação Nacional Dos Magistrados Estaduais vs. National Congress. A) Amendment being questioned: CA 45/2004 (article 1, CA 45/2004); B) Subject: Reform of Judiciary; C) No Amicus Curiae petitions; D) Authorities petitions: Senate; Attorney- 
General; Solicitor-General; E) No preliminary ruling; F) Negative final decision; G) No "Pedido de Vista"; H) No shifting votes.

ADI 3686 - Associação Nacional Dos Membros Do Ministério Público vs. National Congress. A) Amendment being questioned: CA 52/2006 (articles 1 and 2, CA 52/2006);

B) Subject: Party Alliance Systems ("Coligações Partidárias"); C) No Amicus Curiae petitions; D) No authorities petitions; E) No preliminary ruling; F) Negative final decision; G) No "Pedido de Vista"; H) No shifting votes.

ADI 3685 - Conselho Federal Da Ordem Dos Advogados Do Brasil vs. National Congress. A) Amendment being questioned: CA 52/2006 (article 2, CA 52/2006); B) Subject: Party Alliance Systems ("Coligações Partidárias"); C) Amicus Curiae petitions: Partido Social Liberal - PSL (participation denied), Assembleia Legislativa do Estado do Rio de Janeiro, Partido da Frente Liberal - PFL, Partido do Movimento Democrático Brasileiro - PMDB, Partido Democrático Trabalhista - PDT, Partido Popular Socialista PPS; D) Authorities petitions: Senate; Attorney-General; Solicitor-General; E) No preliminary ruling; F) Positive ffinal decision; G) No "Pedido de Vista"; H) No shifting votes.

ADI 3684 - Solicitor-General of the Republic vs. National Congress. A) Amendment being questioned: CA 45/2004 (article 114, I and IV, Federal Constitution); B) Subject: competence of the Labour Justice ("Reforma do Judiciário"); C) Amicus Curiae petitions: Associação Nacional dos Procuradores do Trabalho, Associação Nacional dos Magistrados da Justiça do Trabalho.; D) Authorities petitions: Senate; House of Representatives (only formal analysis); Attorney-General; E) Positive preliminary ruling (Collegiate - plenary); F) No final decision; G) No "Pedido de Vista"; H) No shifting votes.

ADI 3472 - Associação Nacional Dos Membros Do Ministério Público vs. National Congress. A) Amendment being questioned: CA 45/2004 (art. 5, § 1, CA 45/2004); B) Subject: Attributions of the National Council of Justice ("Reforma do Judiciário"); C) No Amicus Curiae petitions; D) Authorities petitions: Senate; Attorney-General; SolicitorGeneral; E) Positive preliminary ruling (Collegiate - plenary); F) Negative final decision; G) No "Pedido de Vista"; H) No shifting votes. 
ADI 3529 - Associação Nacional Dos Magistrados Estaduais vs. National Congress. A) Amendment being questioned: CA 45/2004 (article 1, CA 45/2004); B) Subject: Competence of the Labour Justice ("Reforma do Judiciário"); C) No Amicus Curiae petitions; D) No authorities petitions; E) No preliminary ruling; F) No final decision; G) No "Pedido de Vista"; H) No shifting votes.

ADI 3395 - Associação Dos Juízes Federais Do Brasil vs. National Congress. A) Amendment being questioned: CA 45/2004 (article 114, I, Federal Constitution); B) Subject: Competence of the Labour Justice; C) Amicus Curiae petitions: Associação dos Magistrados da Justiça do Trabalho, Associação Nacional dos Procuradores do Trabalho; D) Authorities petitions: Senate; Attorney-General; Solicitor-General; E) Preliminary ruling (Individual - Justice Nelson Jobim (27/01/2005); confirmed by the plenary (05/04/2006)); F) No final decision; G) No "Pedido de Vista"; H) No shifting votes.

ADI 3367 - Associação Dos Magistrados Brasileiros vs. National Congress. A) Amendment being questioned: CA 42/2004 (articles 1 and 2, CA 42/2004); B) Subject: Creation of the National Council of Justice; C) No Amicus Curiae petitions; D) Authorities petitions: Senate; Attorney-General; Solicitor General; E) No preliminary ruling; F) Negative final decision; G) No "Pedido de Vista"; H) No shifting votes.

ADI 3363 - Associação Nacional Dos Magistrados Da Justiça Do Trabalho vs. National Congress. Joint processing (ADIs 3308, 3363, 4802, 4803). A) Amendment being questioned: CA 20/1998 and CA 21/2003(article 1, CA 20/1998, article 2, §§ 2 and 3, CA 41/2003). B) Subject: Judges' Social Security System ("Reforma da Previdência"); C) Amicus Curiae petitions: Associação do Ministério Público do Distrito Federal e Territórios; D) Authorities petitions: Senate; Attorney-General; Solicitor-General; E) No preliminary ruling; F) No final decision; G) No "Pedido de Vista"; H) No shifting votes.

ADI 3308 - Associação Nacional Dos Magistrados Da Justiça Do Trabalho vs. National Congress. Joint processing (ADIs 3308, 3363, 4802, 4803). A) Amendment being questioned: CA 20/1998 and CA 21/2003(article 1, CA 20/1998, article 2, §§ 2 and 3, CA 41/2003); B) Subject: Judges' Social Security System ("Reforma da Previdência"); C) Amicus Curiae petitions: Associação o Ministério Público do Distrito Federal e Territórios, 
Associação Nacional dos Membros do Ministério Público; D) Authorities petitions: Senate; House of Representatives; Attorney-General; Solicitor-General; E) No preliminary ruling; F) No final decision; G) No "Pedido de Vista"; H) No shifting votes.

ADI 3297 - Associação Dos Magistrados Brasileiros vs. National Congress. A) Amendment being questioned: CA 41/2003 (article 1, CA 41/2003); B) Subject: Judges' Social Security Systems and Subsidies; C) Amicus Curiae petitions: Sindicato dos Agentes Fiscais de Rendas do Estado de São Paulo; D) Authorities petitions: Senate; Attorney-General; Solicitor-General; E) No preliminary ruling; F) No final decision; G) No "Pedido de Vista"; H) No shifting votes.

ADI 3291 - Associação Nacional Dos Magistrados Da Justiça Do Trabalho vs. National Congress. Joint processing (ADIs 3291 and 3104); A) Amendment being questioned: CA 41/2003 (articles 2 and 10, CA 41/2003); B) Subject: Judges' Social Security System ("Reforma da Previdência"); C) No Amicus Curiae petitions; D) No authorities petitions; E) No preliminary ruling; F) Negative final decision; G) No "Pedido de Vista"; H) No shifting votes.

ADI 3184 - Associação Dos Magistrados Brasileiros vs. National Congress. A) Amendment being questioned: CA 41/2003 (article 1, CA 41/2003); B) Subject: Social Security System ("Reforma da Previdência"); C) Amicus Curiae petitions: Sindicato Nacional dos Docentes das Instituições de Ensino Superior, Federação Nacional dos Auditores Fiscais da Previdência Social, Sindicato dos Trabalhos do Poder Judiciário e do Ministério Público da União no Distrito Federal, Federal Nacional dos Trabalhadores do Judiciário Federal e Ministério Público da União, Sindicato Nacional dos Auditores Fiscais da Receita Federal.; D) Authorities petitions: Attorney-General; SolicitorGeneral; E) No preliminary ruling; F) No final decision; G) "Pedido de Vista": Justice Ayres Britto (Requested: 21/09/2011; Returned: 18/12/2018 - Justice Carmen Lúcia; 2645 days); H) No shifting votes.

ADI 3172 - Associação Nacional Dos Magistrados Da Justiça Do Trabalho vs. National Congress. A) Amendment being questioned: CA 41/2003 (article 1, CA 41/2003); B) Subject: Judges' Social Security System ("Reforma da Previdência"); C) Amicus Curiae petitions: Sindicato Nacional dos Docentes das Instituições de Ensino Superior, 
Federação Nacional dos Auditores Fiscais da Previdência Social, Sindicato dos Trabalhos do Poder Judiciário e do Ministério Público da União no Distrito Federal, Federal Nacional dos Trabalhadores do Judiciário Federal e Ministério Público da União, Sindicato Nacional dos Auditores Fiscais da Receita Federal; D) Authorities petitions: Attorney-General; Solicitor-General; E) No preliminary ruling; F) Negative final decision; G) No "Pedido de Vista"; H) No shifting votes.

ADI 3143 - Confederação Dos Servidores Públicos Do Brasil vs. National Congress. A) Amendment being questioned: CA 41/2003 (article 1, CA 41/2003); B) Subject: Public Servants' Social Security System ("Reforma da Previdência"); C) Amicus Curiae petitions: Sindicato Nacional dos Docentes das Instituições de Ensino Superior, Federação Nacional dos Auditores Fiscais da Previdência Social, Sindicato dos Trabalhos do Poder Judiciário e do Ministério Público da União no Distrito Federal, Federal Nacional dos Trabalhadores do Judiciário Federal e Ministério Público da União, Sindicato Nacional dos Auditores Fiscais da Receita Federal, Sindicato Nacional dos Procuradores da Previdência Social (participation denied); D) Authorities petitions; Senate; AttorneyGeneral; Solicitor-General; E) No preliminary ruling; F) No final decision; G) "Pedido de Vista": Justice Ayres Britto (Requested: 21/09/2011; Returned: 18/12/2018 - Justice Carmen Lúcia; 2645 days); H) No shifting votes.

ADI 3138 - Associação Dos Magistrados Brasileiros vs. National Congress. A) Amendment being questioned: Ca 41/2003 (article 1, CA 41/2003); B) Subject: Social Security Contribution ("Reforma da Previdência"); C) Amicus Curiae petitions: Sindicato Nacional dos Docentes das Instituições de Ensino Superior; D) Authorities petitions: Senate; Attorney-General; Solicitor-General; E) Negative preliminary ruling (collegiate plenary); F) Negative final decision; G) No "Pedido de Vista"; H) No shifting votes.

ADI 3133- Partido De Reedificação Da Ordem Nacional - PRONA vs. National Congress. A) Amendment being questioned CA 41/2003 (articles 1 and, 4, caput, I and II, CA 41/2003) B) Subject: Social Security System ("Reforma da Previdência"); C) Amicus Curiae petitions: Sindicato Nacional dos Docentes das Instituições de Ensino Superior, Federação Nacional dos Auditores Fiscais da Previdência Social, Sindicato dos Trabalhos do Poder Judiciário e do Ministério Público da União no Distrito Federal, Federação Nacional dos Trabalhadores do Judiciário Federal e Ministério Público da 
União, Sindicato Nacional dos Auditores Fiscais da Receita Federal; D) Authorities petitions: Attorney-General; Prosecutor-General; E) No preliminary ruling; F) No final decision; G) "Pedido de Vista": Justice Ayres Britto (Requested: 21/09/2011; Returned: 18/12/2018 - Justice Carmen Lúcia; 2645 days); H) No shifting votes.

ADI 3128 - Associação Nacional Dos Procuradores da República vs. National Congress. A) Amendment being questioned: CA 41/2003 (article 4, CA 41/2003); B) Subject: Social Security System ("Reforma da Previdência"); C) Amicus Curiae petitions: Sindicato Nacional dos Docentes das Instituições de Ensino Superior, Sindicato dos Trabalhos do Poder Judiciário e do Ministério Público da União no Distrito Federal, Federação Nacional dos Trabalhadores do Judiciário Federal e Ministério Público da União, Sindicato Nacional dos Auditores Fiscais da Receita Federal.; D) Authorities petitions: Senate; Attorney-General; E) No preliminary ruling; F) No final decision; G) "Pedido de Vista": Justice Cesar Peluzo (Requested: 23/06/2004; Returned: 17/08/2004; 55 days); H) No shifting votes.

ADI 3105 - Associação Nacional Dos Membros Do Ministério Público vs. National Congress. A) Amendment being questioned: CA 41/2003 (article 4, CA 41/2003); B) Subject: Social Security System ("Reforma da Previdência"); C) Amicus Curiae petitions: Associação Nacional dos Auditores Fiscais da Previdência Social, Associação Nacional dos Advogados da União, Sindicato dos Trabalhadores do Judiciário Federal e Ministério Público da União, Sindicato Nacional dos Docentes das Instituições de Ensino Superior, Federação Nacional dos Auditores Fiscais da Previdência Social, Sindicato dos Policiais Civis de Londrina e Região, Associação Nacional dos Advogados da União e dos Advogados das Entidades Federais, ASSINPM, CBOPPM-PB, COPMPB, Associação dos Procuradores Federais no Estado do Rio de Janeiro; D) Authorities petitions: Senate; Attorney-General; Solicitor-General; E) No preliminary ruling; F) Partially positive final decision; G) "Pedido de Vista": Justice Cesar Peluzo (Requested: 23/06/2004; Returned: 17/08/2004; 55 days); H) No shifting votes.

ADI 3104 - Associação Nacional Dos Membros Do Ministério Público vs. National Congress. A) Amendment being questioned: CA 41/2003 (articles 2 and 10, CA 41/2003); B) Subject: Social Security System ("Reforma da Previdência"); C) Amicus Curiae petitions: Associação Nacional dos Auditores Fiscais da Previdência Social, Associação Nacional 
dos Advogados da União, Sindicato dos Trabalhadores do Judiciário Federal e Ministério Público da União, Sindicato Nacional dos Docentes das Instituições de Ensino Superior, Federação Nacional dos Auditores Fiscais da Previdência Social; D) No Authorities petitions: Senate; Solicitor-General; E) No preliminary ruling; F) Negative final decision; G) No "Pedido de Vista"; H) No shifting votes.

ADI 3099 - Partido Democrático Trabalhista - PDT vs. National Congress. A) Amendment being questioned: CA 41/2003 (articles 1 and 4, CA 41/2003); B) Subject: Social Security System ("Reforma da Previdência"); C) Amicus Curiae petitions: Associação Nacional dos Auditores Fiscais da Previdência Social, SINDIPÚBLICO/ES, SINDIUPES, SINDIJUDICIÁRIO/ES, SINDISAÚDE/ES, ASSINPOL/ES, Sindicato Nacional dos Técnicos da Receita Federal, Associação Nacional dos Auditores Fiscais da Previdência Social, Associação Nacional dos Advogados da União, Sindicato dos Trabalhadores do Judiciário Federal e Ministério Público da União, Sindicato Nacional dos Docentes das Instituições de Ensino Superior, Federação Nacional dos Auditores Fiscais da Previdência Social.; D) Authorities petitions: Senate; Solicitor-General; E) No preliminary ruling; F) Negative final decision; G) No "Pedido de Vista"; H) No shifting votes.

ADI 2883 - Partido Verde - PV vs. National Congress. A) Amendment being questioned: CA 20/1998 (article 1, CA 20/1998); B) Subject: Social Security System ("Reforma da Previdência"); C) No Amicus Curiae petitions: ; D) Authorities petitions: Senate; Attorney-General; Solicitor-General; E) No preliminary ruling; F) Negative final decision; G) No "Pedido de Vista"; H) No shifting votes.

ADI 2760 - Partido Social Liberal - PSL vs. National Congress. A) Amendment being questioned: CA 20/1998 (article 1, CA 20/1998); B) Subject: Social Security System ("Reforma da Previdência"); C) No Amicus Curiae petitions; D) Authorities petitions: Attorney-General; Solicitor-General; E) No preliminary ruling; F) Negative final decision; G) No "Pedido de Vista"; H) No shifting votes.

ADI 2732 - Confederação Nacional Do Comércio vs. National Congress. A) Amendment being questioned: CA 29/2000 (article 3, CA 2000); B) Subject: Progressive Taxation ("IPTU Progressivo"); C) Amicus Curiae petitions: Município de São Paulo; D) 
Authorities petitions: Senate; Attorney-General; Solicitor-General; E) No preliminary ruling; F) Negative final decision; G) No "Pedido de Vista"; H) No shifting votes.

ADI 2673 - Partido Socialista Brasileiro - PSB vs. National Congress. A) Amendment being questioned: CA 37/2002 (article 4); B) Subject: Creation of a New Tax ("CPMF");

C) No Amicus Curiae petitions; D) Authorities petitions: Senate; Attorney-General; Solicitor-General; E) No preliminary ruling; F) Negative final decision; G) No "Pedido de Vista"; H) No shifting votes.

ADI 2666 - Partido Social Liberal - PSL vs. National Congress. A) Amendment being questioned: CA 37/2002 (article 3, CA 37/02); B) Subject: Creation of a New Tax (“CPMF"); C) No Amicus Curiae petitions; D) Authorities petitions: Senate; AttorneyGeneral; Solicitor-General; E) No preliminary ruling; F) Negative final decision; G) No "Pedido de Vista"; H) No shifting votes.

ADI 2395 -Mesa Da Assembleia Legislativa Do Estado Do Rio Grande Do Sul vs. National Congress. A) Amendment being questioned: CA 15/1996 (article 18, § 4, Federal Constitution; B) Subject: Creation, Merger and Dismemberment of Municipalities; C) No Amicus Curiae petitions; D) Authorities petitions: Senate; Attorney-General; Solicitor-General; E) No preliminary ruling; F) Negative final decision; G) No "Pedido de Vista"; H) No shifting votes.

ADI 2362 - Conselho Federal Da Ordem Dos Advogados Do Brasil vs. National Congress. Joint Processing (ADIS 2362 and 2356). A) Amendment being questioned: CA 30/2000 (article 2, CA 30/2000; B) Subject: Public Payment Orders ("Precatórios"); C) No Amicus Curiae petitions; D) Authorities petitions: Solicitor-General; E) Positive preliminary ruling (Collegiate - plenary); F) No final decision; G) "Pedido de Vista": Justice Ellen Gracie (Requested: 18/02/2002; Returned: 29/07/2004; 892 days); Justice Cezar Peluso (Requested: 02/09/2004; Returned: 03/07/2009; 1765 days).; H) No shifting votes.

ADI 2356 - Confederação Nacional Da Indústria vs. National Congress. A) Amendment being questioned: CA 30/2000 (article 2, CA 30/2000); B) Subject: Public Payment Orders ("Precatórios"); C) No Amicus Curiae petitions; D) Authorities petitions: Senate; E) 
Positive preliminary ruling (Collegiate - Plenary); F) No final decision; G) "Pedido de Vista": Justice Ellen Gracie (Requested: 18/02/2002; Returned: 29/07/2004; 892 days); Justice Cezar Peluso (Requested: 02/09/2004; Returned: 03/07/2009; 1765 days); H) No shifting votes.

ADI 2242 - Mesa Da Assembleia Legislativa Do Estado Do Paraná vs. National Congress. A) Amendment being questioned: CA 20/1998 (article 93, VI, Federal Constitution); B) Subject: Public Servants' Social Security System ("Reforma da Previdência"); C) No Amicus Curiae petitions; D) Authorities petitions: Senate; E) No preliminary ruling; F) Negative final decision; G) No "Pedido de Vista"; H) No shifting votes.

ADI 2159 - Partido Social Liberal - PSL vs. National Congress. A) Amendment being questioned: CA 19/1998 (article 7, CA 19/1998); B) Subject: Justices' subsidies ("Reforma Administrativa"); C) No Amicus Curiae petitions; D) Authorities petitions: Senate; House of Representatives; Attorney-General; Solicitor-General; E) No preliminary ruling; F) Negative final decision; G) No "Pedido de Vista"; H) No shifting votes.

ADI 2135 - Partido Dos Trabalhadores - PT, Partido Democrático Trabalhista - PDT, Partido Comunista Do Brasil - PC DO B, Partido Socialista Do Brasil - PSB vs. National Congress. A) Amendment being questioned: CA 19/1998; B) Subject: Public Servants' Subsidies ("Reforma Administrativa"); C) Amicus Curiae petitions: Sindicato dos Trabalhadores em Saúde Preventiva e Combate às Endemias do Estado do Rio de Janeiro, Conselho Federal de Farmácia, Conselho Regional de Corretores de Imóveis do Rio de Janeiro, Conselho Federal de Engenharia e Agronomia, Federal Nacional dos Trabalhadores do Judiciário Federal e do Ministério Público da União, Federal Nacional dos Trabalhadores nas Autarquias de Fiscalização do Exercício Profissional e nas Entidades Coligadas e Afins (participation denied), Sindicato Nacional dos Trabalhadores em Fundações Públicas Federais em Geografia e Estatística (participation denied), Conselho Federal de Administração (participation denied), Sindicato dos Trabalhadores do Serviço Público Federal no Estado do Rio de Janeiro, Associação Nacional dos Beneficiados pela Lei n.․ 8.878/94 (participation denied); D) Authorities petitions: Senate; Attorney-General; Solicitor-General; E) Partially positive preliminary ruling (Collegiate - Plenary); F) No final decision; G) "Pedido de Vista": Justice Ellen 
Gracie (Requested: 08/11/2001; Returned: 27/06/2002; 231 days); Justice Nelson Jobim (Requested: 27/06/2002; Returned: 23/03/2006; 1365 days), Justice Ricardo Lewandowski (Requested: 23/03/2006, Returned: 18/04/2006; 26 days); Justice Cezar Peluso (Requested: 22/06/2006; Returned: 26/06/2007; 369 days); H) No shifting votes.

ADI 2096 - Confederação Nacional Dos Trabalhadores Da Indústria vs. National Congress. A) Amendment being questioned: CA 20/1998; B) Subject: Minor's Labour Restrictions; C) No Amicus Curiae petitions; D) Authorities petitions: Senate; House of Representatives; Attorney-General; Solicitor-General; E) No preliminary ruling; F) No final decision; G) No "Pedido de Vista"; H) No shifting votes.

ADI 2047 - Partido Comunista Do Brasil - PC DO B vs. National Congress. A) Amendment being questioned: CA 19/1998 (full text); B) Subject: Public Servants' tenure; C) No Amicus Curiae petitions; D) No authorities petitions; E) No preliminary ruling; F) Negative final decision; G) No "Pedido de Vista"; H) No shifting votes.

ADI 2031 - Partido Dos Trabalhadores - PT vs. National Congress. Joint processing (ADIs 2031, 2027). A) Amendment being questioned: CA 21/1998 (full text); B) Subject: Extension of Tax Validity ("CPMF"); C) No Amicus Curiae petitions; D) Authorities petitions: Senate; Attorney-General; Solicitor-General; E) Positive preliminary ruling (Collegiate - Plenary); F) Positive final decision; G) No "Pedido de Vista"; H) No shifting votes.

ADI 2027 - Confederação Nacional Das Profissões Liberais vs. National Congress. Joint processing (ADIs 2031, 2027). A) Amendment being questioned: CA 21/1998 (full text); B) Subject: Extension of Tax Validity ("CPMF"); C) No Amicus Curiae petitions; D) Authorities petitions: Senate; Attorney-General; Solicitor-General; E) Positive preliminary ruling; F) Negative final decision; G) No "Pedido de Vista"; H) No shifting votes.

ADI 2024 - Governor of the State of Mato Grosso do Sul vs. National Congress. A) Amendment being questioned: CA 20/1998 (article 40, § 3, Federal Constitution); B) Subject: Public Servants' Social Security System ("Reforma da Previdência"); C) Amicus Curiae petitions: Sindicato Nacional dos Docentes das Instituições de Ensino Superior, 
Federação Nacional dos Trabalhadores do Poder Judiciário e do Ministério Público da União; D) Authorities petitions: Senate; Attorney-General; Solicitor-General; E) Negative preliminary ruling; F) Negative final decision; G) No "Pedido de Vista"; H) No shifting votes.

ADI 1946 - Partido Socialista Brasileiro - PSB vs. National Congress. A) Amendment being questioned: CA 20/1998 (article 14, CA 20/1998); B) Subject: SociaI Security System ("Reforma da Previdência"); C) No Amicus Curiae petitions; D) Authorities petitions: Senate; House of Representatives; Attorney-General; Solicitor-General; Minister of Social Security and Aid; E) Positive preliminary ruling; F) Partially positive final decision; G) No "Pedido de Vista"; H) No shifting votes.

ADI 1805 - Partido Democrático Trabalhista - PDT, Partido Dos Trabalhadores - PT, Partido Comunista Do Brasil - PC DO B, Partido Liberal - PL vs. National Congress. A) Amendment being questioned: CA 16/997 (article 1, CA 16/1997); B) Subject: Reelection for the Executive offices; C) No Amicus Curiae petitions; D) Authorities petitions: Senate; House of Representatives; Attorney-General; Solicitor-General; E) Negative preliminary ruling; F) No final decision; G) No "Pedido de Vista"; H) No shifting votes.

ADI 1749 - Partido Dos Trabalhadores - PT, Partido Democrático Trabalhista - PDT, Partido Comunista Do Brasil - PC DO B, Partido Do Movimento Democrático Brasileiro - PMDB, Partido Verde - PV vs. National Congress. A) Amendment being questioned: CA 14/1996 (full text); B) Subject: Allocation of Municipalities' budget; C) No Amicus Curiae petitions; D) Authorities petitions: Senate; House of Representatives; AttorneyGeneral; Solicitor-General; E) Negative preliminary ruling (Collegiate - Plenary); F) Negative final decision; G) No "Pedido de Vista"; H) No shifting votes.

ADI 1501 - Confederação Nacional De Dirigentes Lojistas vs. National Congress. Joint processing (ADIs 1501 and 1497). A) Amendment being questioned: CA 12/1996 (full text); B) Subject: Creation of a New Tax (“CPMF”); C) No Amicus Curiae petitions; D) Authorities petitions: Attorney-General; Solicitor-General; E) Negative preliminary ruling; F) Negative final decision; G) "Pedido de Vista": Justice Carlos Velloso (Requested: 18/09/1996; Returned: 09/10/1996; 21 days); H) No shifting votes. 
ADI 1497 - Confederação Nacional Dos Trabalhadores Da Saúde vs. National Congress. Joint processing (ADIs 1501 and 1497). A) Amendment being questioned: CA 12/1996 (full text); B) Subject: Creation of a New Tax (“CPMF”); C) No Amicus Curiae petitions; D) Authorities petitions: Attorney-General; Solicitor-General; E) Negative preliminary ruling; F) Negative final decision; G) No "Pedido de Vista": Justice Carlos Velloso (Requested: 18/09/1996; Returned: 09/10/1996; 21 days); H) No shifting votes.

ADI 1420 - Partido Liberal - PL vs. National Congress. A) Amendment being questioned: CA 10/1996 (articles 1 and 2, CA 10/1996; B) Subject: Creation of the Fiscal Stabilization Fund ("Fundo da Estabilização Fiscal"); C) No Amicus Curiae petitions; D) Authorities petitions: Senate; Attorney-General; E) Negative preliminary ruling; F) Negative final decision; G) No "Pedido de Vista"; H) No shifting votes.

ADI 949 - Conselho Federal Da Ordem Dos Advogados vs. National Congress. A) Amendment being questioned: Ca 3/1993 (article 2, CA 3/1993); B) Subject: Creation of a New Tax ("IPMF"); C) No Amicus Curiae petitions; D) Authorities petitions: AttorneyGeneral; Solicitor-General; E) Negative preliminary ruling; F) Negative final decision; G) No "Pedido de Vista"; H) No shifting votes.

ADI 939 - Confederação Nacional Dos Trabalhados No Comércio vs. National Congress. A) Amendment being questioned: CA 3/1993 (full text); B) Subject: Creation of a New Tax ("IPMF"); C) No Amicus Curiae petitions; D) Authorities petitions: Senate; House of Representatives; Attorney-General; Solicitor-General; E) Positive preliminary ruling; F) Positive final decision; G) No "Pedido de Vista"; H) No shifting votes.

ADI 926 - Governor of the State of Paraná, Governor of the State of Santa Catarina, Governor of the State of Mato Grosso Do Sul, Governor of the State of Mato Grosso vs. National Congress. A) Amendment being questioned: CA 3/1993 (article 2, § 2, CA 3/1993); B) Subject: Creation of a New Tax ("IPMF"); C) No Amicus Curiae petitions; D) Authorities petitions: Senate; Attorney-General; Solicitor-General; E) Positive preliminary ruling; F) Negative final decision; G) No "Pedido de Vista"; H) No shifting votes. 
ADI 913 - Associação Dos Magistrados Brasileiros vs. National Congress. A) Amendment being questioned: CA 3/1993 (article 1, CA 3/1992); B) Subject: Creation of New Judicial Procedures ("Ação Declaratória de Constitucionalidade"); C) No Amicus Curiae petitions; D) No authorities petitions; E) No preliminary ruling; F) Negative final decision; G) No "Pedido de Vista"; H) No shifting votes.

ADI 833 - Governor of the State of Paraná vs. National Congress. A) Amendment being questioned: CA 2/1992 (full text); B) Subject: Referendum to define the system of government; C) No Amicus Curiae petitions; D) Authorities petitions: Attorney-General; Solicitor-General; E) Negative preliminary ruling; F) Negative final decision; G) "Pedido de Vista": Justice Marco Aurélio (Requested: 17/02/1993; Returned: 04/03/1993; 15 days); H) No shifting votes.

ADI 830 - Partido Socialista Brasileiro - PSB, Partido Democrático Trabalhista - PDT vs. National Congress. A) Amendment being questioned: Ca 2/1992 (full text); B) Subject: Referendum to define the system of government; C) No Amicus Curiae petitions; D) Authorities petitions: House of Representatives; Attorney-General; Solicitor-General; E) No preliminary ruling; F) No final decision; G) No "Pedido de Vista"; H) No shifting votes.

ADI 829 - Partido De Reedificação Da Ordem Nacional - PRONA vs. National Congress. A) Amendment being questioned: CA 2/1992 (full text); B) Subject: Referendum to define the system of government; C) No Amicus Curiae petitions; D) Authorities petitions: Senate; Attorney-General; Solicitor-General; E) No preliminary ruling; F) Negative final decision; G) No "Pedido de Vista"; H) No shifting votes. 


\section{ANNEX 3 - PERUVIAN CONSTITUTIONAL COURT DECISIONS (“AIs”) REVIEWING CONSTITUTIONAL AMENDMENTS}

FILES: Number of the AI; Plaintiffs; Defendants; A) Dates of filing and final decision; B) Amendment being questioned; C) Subject; D) Congress' Answer to the Complaint; E) Presence or absence of oral hearings; F) Final decisions.

AI 00050-2004 - Colegio del Abogados del Cusco vs. National Congress. Joint processing ( $A I^{\prime}$ 's 00050-2004; 00051-2004; 00004-2005; 00007-2005; 00009-2005) A) Filed: 06/12/2004; Final Decision: 06/06/2005. B) Amendment being questioned: Ley de Reforma Constitucional N.. 28389 (articles 1, 2, and 3, LRC № 28389). C) Subject: Social Security System; D) National Congress participation; E) Oral Hearings (04/05/2005); F) Amendment ruled partially unconstitutional (unanimous).

AI 00051-2004 - Colegio del Abogados del Callao vs. National Congress. Joint processing ( $A I^{\prime}$ 's 00050-2004; 00051-2004; 00004-2005; 00007-2005; 00009-2005) A) Filed: 07/12/2004; Final Decision: 06/06/2005. B) Amendment being questioned: Ley de Reforma Constitucional N. 28389 (article 3, LRC № 28389). C) Subject: Social Security System; D) 
National Congress participation; E) Oral Hearings (04/05/2005); F) Amendment ruled partially unconstitutional (unanimous).

AI 00004-2005 - 5.000 Peruvian Citizens (Juan Figueroa and others) vs. National Congress. Joint processing (AI's 00050-2004; 00051-2004; 00004-2005; 00007-2005; 000092005) A) Filed: 15/02/2005; Final Decision: 06/06/2005. B) Amendment being questioned: Ley de Reforma Constitucional N.o 28389 (article 3, LRC № 28389). C) Subject: Social Security System; D) National Congress participation; E) Oral Hearings (04/05/2005); F) Amendment ruled partially unconstitutional (unanimous).

AI 00007-2005 - 6.744 Peruvian Citizens (Raul Vizcardo Otazo and others) vs. National Congress. Joint processing ( $A I^{\prime}$ 's 00050-2004; 00051-2004; 00004-2005; 00007-2005; 000092005) A) Filed: 03/03/2005; Final Decision: 06/06/2005. B) Amendment being questioned: Ley de Reforma Constitucional N.o 28389 (article 3, LRC № 28389). C) Subject: Social Security System; D) National Congress participation; E) Oral Hearings (04/05/2005); F) Amendment ruled partially unconstitutional (unanimous).

AI 00009-2005 - Colegio de Abogados del Cusco vs. National Congress. Joint processing ( $A I^{\prime}$ 's 00050-2004; 00051-2004; 00004-2005; 00007-2005; 00009-2005) A) Filed: 09/03/2005;

Final Decision: 06/06/2005. B) Amendment being questioned: Ley de Reforma Constitucional N.․․ 28389 (article 3, LRC № 28389). C) Subject: Social Security System; D) National Congress participation; E) Oral Hearings (04/05/2005); F) Amendment ruled partially unconstitutional (unanimous).

AI 00029-2005 - Gobierno Regional de Loreto (Robinson Riyadeneyra Reatequi) vs. National Congress. A) Filed: 02/11/2005; Final Decision: 11/01/2006. B) Amendment being questioned: Ley de Reforma Constitucional N.. 28607 (full text). C) Subject: Electoral Rules ("Incompatibilidad Electoral"); D) No Congress manifestation; E) No Oral Hearings; F) Ruled inhibited (unanimous).

AI 00010-2017 - Colegio de Abogados de Piura vs. The President of Peru. A) Filed: 07/08/2017; Final Decision: 23/01/2018. B) Amendment being questioned: Proyecto de Ley de Reforma Constitucional N. ${ }^{\circ}$ 1720/2017 (full text). C) Subject: National Judiciary Council; 
D) No Congress manifestation; F) No Oral Hearings; G) Ruling: Impossibility of judicial review of amendment proposals (unanimous).

AI 00008-2018 - 5.323 Peruvian Citizens (Jesus Galindo Alvizuri and others) vs. National Congress. A) Filed: 12/04/2018; Final Decision: 05/10/2018. B) Amendment being questioned: Ley de Reforma Constitucional N. 030305 (full text). C) Subject: Electoral Rules - Mayors' Re-election; D) Congress manifestation; E) Oral Hearings (24/08/2018); F) Amended ruled constitutional (4 separate opinions).

\section{ANNEX 4 - BRAZILIAN JUSTICES APPOINTED BY EACH PRESIDENT}

(Supreme Court's Composition since 1988)

\begin{tabular}{|l|c|l|}
\hline Justice & Years in Court & Appointed by the President \\
\hline Moreira Alves & $1975-2003$ & Ernesto Geisel -Military \\
\hline Neri da Silveira & $1981-2002$ & João Figueiredo - Military \\
\hline Aldir Passarinho & $1982-1991$ & João Figueiredo - Military \\
\hline Sidney Sanches & $1984-2003$ & João Figueiredo - Military \\
\hline Octavio Gallotti & $1984-2000$ & João Figueiredo -Military \\
\hline Carlos Madeira & $1985-1990$ & João Figueiredo - Military \\
\hline Célio Borja & $1986-1992$ & José Sarney \\
\hline Paulo Brossard & $1989-1994$ & José Sarney \\
\hline Sepúlveda Pertence & $1989-2007$ & José Sarney \\
\hline Celso de Mello & $1989-n o w$ & José Sarney \\
\hline Marco Aurélio & $1990-n o w$ & Fernando Collor \\
\hline Ilmar Galvão & $1991-2003$ & Fernando Collor \\
\hline Francisco Rezek & $1992-1997$ & Fernando Collor \\
\hline Maurício Côrrea & $1994-2004$ & Itamar Franco \\
\hline Nelson Jobim & $1997-2006$ & Fernando Henrique Cardoso (FHC) \\
\hline Ellen Gracie & $2000-2011$ & Fernando Henrique Cardoso (FHC) \\
\hline Gilmar Mendes & $2002-n o w$ & Fernando Henrique Cardoso (FHC) \\
\hline Cezar Peluso & $2003-2012$ & Luis Inácio Lula da Silva (Lula) \\
\hline
\end{tabular}




\begin{tabular}{|c|c|c|}
\hline Ayres Britto & $2003-2012$ & Luis Inácio Lula da Silva (Lula) \\
\hline Joaquim Barbosa & 2003-2014 & Luis Inácio Lula da Silva (Lula) \\
\hline Eros Grau & $2004-2010$ & Luis Inácio Lula da Silva (Lula) \\
\hline Ricardo Lewandowski & 2006-now & Luis Inácio Lula da Silva (Lula) \\
\hline Cármen Lúcia & 2006-now & Luis Inácio Lula da Silva (Lula) \\
\hline Menezes Direito & 2007-2009 & Luis Inácio Lula da Silva (Lula) \\
\hline Dias Toffoli & 2009-now & Luis Inácio Lula da Silva (Lula) \\
\hline Luiz Fux & 2011-now & Dilma Rousseff \\
\hline Rosa Weber & 2011-now & Dilma Rousseff \\
\hline Teori Zavascki & 2012-now & Dilma Rousseff \\
\hline Roberto Barroso & 2013-now & Dilma Rousseff \\
\hline Edson Fachin & 2015-now & Dilma Rousseff \\
\hline Alexandre de Moraes & 2017-now & Michel Temer \\
\hline
\end{tabular}

\section{ANNEX 5 - ANNEX 5 - CONSTITUTIONAL AMENDMENT PROCEDURES AND COURT'S INSTITUTIONAL INFORMATION}

(Argentina, Brazil, Colombia, And Peru)

\section{FILES - Country: A) Amendment Procedure (Constitutional Provision); B) Number of Justices; C) Justice's Appointment Procedure; D) Justice's Mandate; E) Competence for judicial review.}

Argentina: A) Congress (2/3 quorum) must declare the need for a reform. A Convention then takes place in order to change the Constitution (Article 30, Constitution of 1853); B) 5 justices (since 2006); C) Justice appointed by the President and confirmed by the Senate (2/3 quorum); D) Life Tenure (retirement: 75 years old, with the opportunity to keep the role for 5 years depending on the President and Senate confirmation); E) Concrete judicial review. 
Brazil: A) Congress (2/3 quorum each house, in two turns). Constitutional amendments may be proposed by $1 / 3$ of the House of Representatives or the Senate; the President of the Republic; or more than half of the State Legislative (by simple majority in each State) (Article 60, Constitution of 1988). B) 11 justices; C) Justice appointed by the President and confirmed by the Senate (absolute majority); D) Life Tenure (retirement: 75 years old); E) Concrete and abstract judicial review.

Colombia: A) Congress (first round, simple majority; second round, absolute majority) plus possibility of new Constituent Assembly. Constitutional amendments may be proposed by $5 \%$ of the electorate or 35\% of the congressmen (Articles 155 and 375, Constitution of 1991). B) 9 justices; C) Justices appointed by the President, the Supreme Court, and the Council of State, in ternary lists; D) 8 years mandate, without re-election; E) Concrete and abstract judicial review.

Peru: A) Congress (absolute majority) plus ratification by popular referendum or two thirds of Congress in two successive ordinary legislatures (Article 206, Constitution of ); B) 7 justices; C) Justice appointed by Congress (2/3 quorum); D) 5 years, without immediate re-election; E) Concrete an 


\section{ANNEX 6 - COLOMBIAN COURT DECISIONS IN ABSTRACT REVIEW REVIEWING CONSTITUTIONAL AMENDMENTS}

FILES: Number given to the case; Plaintiffs; Defendants; A) Amendment being questioned; B) Subject; C) Interventions (including amicus curiae); D) SolicitorGeneral position; E) Final ruling; F) Date of final ruling.

C-027-93 - Orlando Fals Borda and Adalberto Carvajal Salcedo vs. National Congress; A) Amendment being questioned: CA ("Acto Legislativo") 001/1996 (full text); B) Subject: Electoral Reform (Composition and Competence of State Assemblies); C) Interventions: Ministry of Interior; 1 citizen; D) Solicitor-General position: for the constitutionality; E) Ruled constitutional (unanimous); F) April 27, 1997.

C-387-97 - Manuel Barreto Soler, Carlos Rodríguez Mejía, and Gustavo Gallón Giraldo vs. National Congress; A) Amendment being questioned: CA ("Acto Legislativo") 002/1995 (full text); B) Subject: Competence of the Military Justice; C) Interventions: 
Ministry of Defence; D) Solicitor-General position: for the constitutionality; E) Ruled constitutional (non-unanimous); F) August 19, 1997.

C-1200-03 - Antonio José Cancino Moreno, David Teleki Ayala and other 17 citizens vs. National Congress; A) Amendment being questioned: CA ("Acto Legislativo") 003/2002 (articles 4 and 5); B) Subject: Extraordinary Presidential Powers; C) Interventions: Ministry of Interior and Justice; Universidad Santo Tomás; Attorney-General; D) SolicitorGeneral position: for the constitutionality; E) Ruled for the inhibition of the case (nonunanimous); F) December 9, 2003.

C-208-05 - Paula Cadavid Londoño vs. National Congress; A) Amendment being questioned: CA ("Acto Legislativo") 001/2003 (article 13, itens 3 and 4); B) Subject: Electoral Reform ("voto en lista"); C) Interventions: Ministry of Interior and Justice; National Electoral Council; Academia Colombiana de Jurisprudencia; Universidad del Rosario; D) Solicitor-General position: for the constitutionality; E) Ruled constitutional (non-unanimous); F) March 10, 2005.

C-1040-05 - Blanca Linday Enciso vs. National Congress; A) Amendment being questioned: CA ("Acto Legislativo") 002/2004 (full text); B) Subject: Presidential Reelection; C) Interventions: President of the Republic; National Congress; Ministry of Interior and Justice; Academia Colombiana de Jurisprudencia; Pontificia Universidad Javeriana; Universidad Antioquia; Universidad del Norte; Senator Hernán Andrade Serrano; Governor of Valle del Cauca; Universidad Popular del César; 6 citizens; Universidad Sergio Arboleda; D) Solicitor-General position: for the unconstitutionality; E) Ruled partially unconstitutional (non-unanimous); F) October 19, 2005.

C-1041-05 - Wilson Afonso Borja Díaz vs. National Congress; A) Amendment being questioned: CA ("Acto Legislativo") 002/2004 (full text); B) Subject: Presidential Reelection; C) Interventions: Ministry of Interior and Justice; National Congress; Senator Hernán Andrade Serrano; 9 citizens; Universidad Sergio Arboleda; D) Solicitor-General position: for the unconstitutionality; E) Ruled partially unconstitutional (nonunanimous); F) October 19, 2005. 
C-1053-05 - Jairo Bautista vs. National Congress; A) Amendment being questioned: CA ("Acto Legislativo") 002/2004 (full text); B) Subject: Presidential Re-election; C) Interventions: Ministry of Interior and Justice; National Congress; 3 citizens; Governor of Valle del Cauca; D) Solicitor-General position: for the unconstitutionality; E) Ruled constitutional (non-unanimous); F) October 19, 2005.

C-178-07 - Elson Rafael Rodrigo Rodríguez Beltrán vs. National Congress; A) Amendment being questioned: CA ("Acto Legislativo") 001/2005 (articles 1 and 2); B) Subject: Social Security Reform; C) Interventions: Ministry of Finance; Ministry of Social Protection D) Solicitor-General position: for the constitutionality; E) Ruled constitutional (non-unanimous); F) March 14, 2007.

C-588-09 - Mauricio Bedoya Vidal vs. National Congress; A) Amendment being questioned: CA ("Acto Legislativo") 001/2008 (article 1); B) Subject: Administrative Reform (Public Service Regime); C) Interventions: National Committee on Civil Service; Public Servants' Administrative Department; Universidad del Rosario; Confederación de Trabajadores de Colombia - C.T.C; Sindicato Nacional de Servidores Públicos de las Empresas Sociales del Estado - SINALTRAESES; Asociación de Etnoeducadores Afrocolombianos del Pacífico Sur - MARES; 8 citizens. D) Solicitor-General position: for the unconstitutionality; E) Ruled unconstitutional (non-unanimous); F) August 27, 2009.

C-141-10 - No Plaintiff (case of automatic judicial review); A) Amendment being questioned: Law ("Ley") n.. 1354/2009 (Proposed Constitutional Amendment, with a pending referendum); B) Subject: Presidential Re-election; C) Interventions: 1.278 citizens; D) Solicitor-General position: for the partial unconstitutionality; E) Ruled unconstitutional (non-unanimous); F) February 26, 2010.

C-303-10 - Sonia Patricia Téllez Beltrán vs. National Congress; A) Amendment being questioned: CA ("Acto Legislativo") 001/2009 (article 1, first paragraph); B) Subject: Electoral Reform (Period for shifting parties without sanctions); C) Interventions: Ministry of Interior and Justice; Universidad Nacional de Colombia; Universidad de Ibagué; Universidad del Rosario; Academia Colombiana de Jurisprudencia. D) Solicitor-General 
position: for the constitutionality; E) Ruled constitutional (non-unanimous); F) April 28, 2010.

C-702-10 - Marcos Aníbal Avirama Avirama and Miguel Antonio Gálvis. vs. National Congress; A) Amendment being questioned: CA ("Acto Legislativo") 001/2009 (article 2, item 8); B) Subject: Electoral Reform ("Clausula de barrera" and party affiliation rules for minorities and ethnical groups); C) Interventions: Ministry of Interior and Justice; Universidade Nacional de Colombia. D) Solicitor-General position: for the unconstitutionality; E) Ruled unconstitutional (non-unanimous); F) September 6, 2010.

C-170-12 - Yolanda Naranjo Jaramillo and others vs. National Congress; A) Amendment being questioned: CA ("Acto Legislativo") 002/2011 (full text); B) Subject: TV regulation (concession, control, and services); C) Interventions: Ministry of Interior and Justice; Ministry of Technology, Information, and Communications; Committee on Communication Regulation; National Commission on Television; Universidad del Norte; Universidad Javeriana; Universidad Externado; 5 citizens. D) Solicitor-General position: for the constitutionality; E) Ruled constitutional (non-unanimous); F) March 7, 2012.

C-249-12 - Miguel Ángel González Ocampo, Giovany Alexander Gutiérrez Rodríguez, and Rafael Cañón González vs. National Congress; A) Amendment being questioned: CA ("Acto Legislativo") 004/2011 (full text); B) Subject: Administrative Reform (Public Service Selection Processes); C) Interventions: National Commission on Civil Service; Universidad Externado; 4 citizens. D) Solicitor-General position: for the unconstitutionality; E) Ruled unconstitutional (non-unanimous); F) March 29, 2012.

C-474-13 - Pablo Bustos Sánchez (D-9200) y Alfredo Castaño Martínez (D-9208) vs. National Congress; A) Amendment being questioned: CA ("Acto Legislativo") 007/2011, Proposal of Constitutional Amendment n.. 09, 11, 12, and 13/2011 (full text); B) Subject: Reform of the Judiciary; C) Interventions: Nation Congress; Ministry of Justice and Law; Ministry of Interior; Legal Secretariat of the Presidency; Council of State; 9 citizens; Instituto Colombiano de Derecho Procesal; Partido Polo Democrático Alternativo; Universidad Libre; Colegio de Abogados del Trabajo; Partido Verde; Universidad Santo Tomás; Comisión 
Colombiana de Juristas. D) Solicitor-General position: for the inhibition; E) Ruled inhibited (non-unanimous); F) July 24, 2013.

C-524-13 - Jaime Araujo Rentería vs. National Congress; A) Amendment being questioned: Proposed Constitutional Amendment ("Proyecto de Acto Legislativo") 0072011-Senate/143-2011-House of Representatives (full text); B) Subject: Reform of the Judiciary; C) Interventions: Ministry of Justice; Council of State; Legal Secretariat of the Presidency; Ministry of Interior; Partido Polo Democrático Ativo; Partido Verde; Partido Liberal Colombiano; Centro Colombiano de Derecho Procesal Constitucional; Universidad Externado; 2 citizens. D) Solicitor-General position: for the inhibition; E) Ruled inhibited (non-unanimous); F) August 14, 2013.

C-579-13 - Gustavo Gallón Giraldo and others vs. National Congress. A) Amendment being questioned: CA ("Acto Legislativo") 001/2012 (article 1); B) Subject: Transitional Justice (Human Rights Trials regulation); C) Interventions: National Government (Ministry of Interior; Ministry of Justice; High Commissioner for Peace; Social Prosperity Department; Colombian Agency for Reintegration; Legal Secretariat for the Presidency; Presidential Program on Human Rights and Humanitarian International Law; Attention and Repair for Victims Unit); Fundación de Ideas para la Paz; Centro Internacional para la Justicia Transicional; Universidad Sergio Arboleda; Universidad Libre; Pontificia Universidad Javeriana; Universidad del Rosario; 8 citizens; International Criminal Court; Human Rights Watch; Amnesty International; 5 experts (professors); President of the Republic; Comisión Colombiana de Juristas; President of the Congress; President of the Criminal Chamber of the High Court of Justice; Centro de Estudios de Derecho, Justicia y Sociedad - Dejusticia; Fundación Centro de Pensamiento Primero Colombia; Public Defenders; Centro de Investigación y Educación Popular -CINEP; Attorney-General; CODHES; Fundación País Libre; Asociación Caminos de Esperanza, Madres de la Candelaria; Universidad de los Andes; Universidad del Sinú; Universidad Nacional de Colombia; United Nations High Commissioner for Human Rights in Colombia. D) Solicitor-General position: for the inhibition; E) Ruled constitutional (non-unanimous); F) August 28, 2013.

C-084-16 - Gustavo Gallón Giraldo, Jomary Ortegón Osorio, and others vs. National Congress. A) Amendment being questioned: CA ("Acto Legislativo") 001/2015 (article 1); 
B) Subject: Criminal prosecution for Military crimes (application of Humanitarian International Law); C) Interventions: Ministry of Defence; Legal Secretariat of the Presidency; Universidad Libre; Universidad Santo Tomás; Pontificia Universidad Javeriana; Universidad Externado; Universidad de Ibagué; Universidad Industrial de Santander; Colectivo de Abogados Luis Carlos Pérez; Universidad Militar Nueva Granada; United Nations High Commissioner for Human Rights in Colombia; Comisión Internacional de Juristas; Organización Mundial contra la Tortura; Federación Internacional de Derechos Humanos; Abogados sin Fronteras -ASFC; Garden Court International; Garden Court Chambers; Corporación Acción Humanitaria por la Convivencia y la Paz-Cahopana; Asociación para la Promoción Social Alternativa-Minga; Mesa de trabajo sobre Ejecuciones Extrajudiciales de la Coordinación Colombia, Europa, Estados Unidos; Asociación colombiana de Oficiales en retiro de las Fuerzas Militares -Acore; Centro de Estudios de Derecho, Justicia y Sociedad -Dejusticia; 6 citizens. D) Solicitor-General position: for the inhibition; E) Ruled constitutional (nonunanimous); F) February 24, 2016.

C-230-16 - Jorge Kenneth Burbano Villamarin, Jorge Ricardo Palomares García, Edgar Valdeleón Pabón, and Javier Enrique Santander Díaz vs. National Congress. A) Amendment being questioned: CA ("Acto Legislativo") 002/2015 (article 9); B) Subject: Presidential re-election; C) Interventions: Ministry of Interior; Ministry of Justice and Law; Legal Secretariat of the Presidency; Universidad Javeriana; Universidad Santo Tomás; 6 citizens. D) Solicitor-General position: for the inhibition; E) Ruled inhibited (unanimous); F) May 11, 2016.

C-285-16 - Carlos Santiago Pérez Pinto vs. National Congress. A) Amendment being questioned: CA ("Acto Legislativo") 002/2015 (articles 15, 16, 17, 18, 19, and 26); B) Subject: National Council of Justice; C) Interventions: Academia Colombiana de Jurisprudencia, Ministry of Justice, Ministry of Interior, Universidad de la Sabana, Attorney-General, Corporación Excelencia en la Justicia, 2 citizens, Mesa Regional Caribe y representantes de los distritos judiciales de Bogotá, Medellín y Villavicencio; National Council of Justice; Presidencia de la Sala Administrativa del Consejo Seccional de la Judicatura de Cundinamarca; President of the Criminal Chamber of the High Court of Justice; Council of Justice of Caldas; National Congress; President of the Supreme Court of Justice; Council of State; Court of Appeals of Bogotá; 1 congressman; 2 experts (professors). D) 
Solicitor-General position: for the inhibition; E) Ruled partially unconstitutional (nonunanimous); F) June 1, 2016.

C-699-16 - Jesús Pérez González-Rubio vs. National Congress. A) Amendment being questioned: CA ("Acto Legislativo") 001/2016 (articles 1 and 2); B) Subject: Peace-Building Agreement (Legislative Procedures); C) Interventions: National Government (Ministry of Interior; Ministry of Justice; High Commissioner for Peace; Legal Secretariat of the Presidency; Senior Advisor for Post-Conflict and Human Rights; Attention and Repair of the Victims Unit; National Center of Historical Memory; Colombian Agency for Reintegration; Presidential Advisor for Human Rights; Social Prosperity Department); Public Defenders; Centro de Investigación y Educación Popular; Programa por la Paz CinepPPP; Federación Colombiana de Municipios - Fedemunicipios; Universidad de Cartagena; 46 citizens; Universidad Externado; Universidad Industrial de Santander; Universidad Sergio Arboleda; Colectivo de Abogados José Alvear Restrepo; Corporación Cultura y Educación para la Paz - Cepaz; Mesa Nacional de Participación Efectiva de Víctimas; House of Representatives; Familiares de los Diputados del Valle del Cauca; Partido Centro Democrático; Federación Comunal del Departamento de Putumayo; Mesa de Participación de Víctimas; Red Jóvenes Sinestesia; El Avispero; Paz a la Calle; Seamos Democracia Digital; Paziempre Movimiento Estudiantil; Javerianos por la Paz; Campamento por la Paz. D) Solicitor-General position: for the inhibition; E) Ruled constitutional (non-unanimous); F) December 13, 2016.

C-332-17 - Iván Duque Márquez and others vs. National Congress. A) Amendment being questioned: CA ("Acto Legislativo") 001/2016 (articles 1 and 2); B) Subject: PeaceBuilding Agreement (Legislative Procedures); C) Interventions: National Center of Historic Memory; Academia Colombiana de Jurisprudencia; Conferencia Episcopal de Colombia; Universidad Libre; Universidad del Rosario; Comisión Colombiana de Juristas; Universidad Sergio Arboleda; Universidad Santo Tomás; 14 citizens; 15 senators; Agencia Colombiana para la Reintegración de Personas y Grupos Alzados en Armas; Universidad Militar Nueva Granada; Universidad Industrial de Santander; Universidad Autónoma de Bucaramanga; President of the Senate; Ministry of Interior; High Commissioner for Peace; Council of State; Mesa Nacional de Víctimas; Academia Colombiana de Derecho Internacional. D) Solicitor-General position: for the unconstitutionality; E) Ruled partially unconstitutional (non-unanimous); F) May 17, 2017. 
C-630-17 - No Plaintiff (case of automatic judicial review). A) Amendment being questioned: CA ("Acto Legislativo") 002/2017 (full text); B) Subject: Peace-Building Agreement (Interpretative Guidelines); C) Interventions: Legal Secretariat of the Presidency; Universidad Externado; Universidad Sergio Arboleda; Universidad Santo Tomás de Bogotá; Universidad Libre; Centro de Estudios de Derecho, Justicia y Sociedad - Dejusticia; Comisión Colombiana de Juristas; Colectivo de Abogados "José Alvear Restrepo"; Movimiento Nacional de Víctimas de Crímenes de Estado; Corporación Jurídica Yira Castro; Consultoría para los Derechos Humanos y el Desplazamiento (CODHES); Organización Ruta Pacífica de las Mujeres; 14 citizens. D) Solicitor-General position: for the constitutionality; E) Ruled partially unconstitutional (non-unanimous); F) October 11, 2017. 